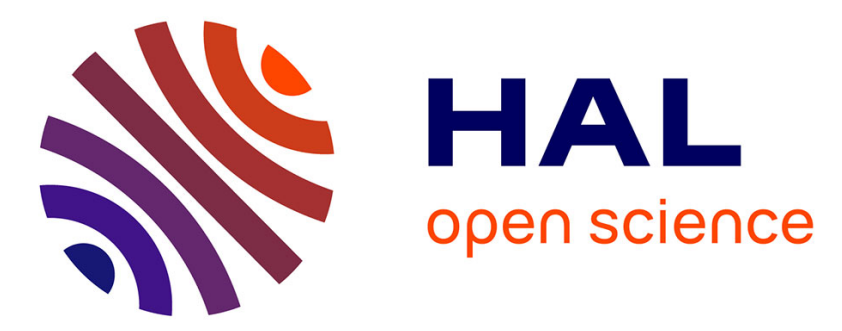

\title{
Stable, Active, and Methanol-Tolerant PGM-Free Surfaces in an Acidic Medium: Electron Tunneling at Play in Pt/FeNC Hybrid Catalysts for Direct Methanol Fuel Cell Cathodes
}

Tomasz Kosmala, Nicolas Bibent, Moulay Tahar Sougrati, Goran Dražić, Stefano Agnoli, Frederic Jaouen, Gaetano Granozzi

\section{To cite this version:}

Tomasz Kosmala, Nicolas Bibent, Moulay Tahar Sougrati, Goran Dražić, Stefano Agnoli, et al.. Stable, Active, and Methanol-Tolerant PGM-Free Surfaces in an Acidic Medium: Electron Tunneling at Play in Pt/FeNC Hybrid Catalysts for Direct Methanol Fuel Cell Cathodes. ACS Catalysis, 2020, 10 (14), pp.7475-7485. 10.1021/acscatal.0c01288 . hal-02918327

\section{HAL Id: hal-02918327 \\ https://hal.umontpellier.fr/hal-02918327}

Submitted on 13 Nov 2020

HAL is a multi-disciplinary open access archive for the deposit and dissemination of scientific research documents, whether they are published or not. The documents may come from teaching and research institutions in France or abroad, or from public or private research centers.
L'archive ouverte pluridisciplinaire HAL, est destinée au dépôt et à la diffusion de documents scientifiques de niveau recherche, publiés ou non, émanant des établissements d'enseignement et de recherche français ou étrangers, des laboratoires publics ou privés. 


\section{Stable, Active and Methanol Tolerant PGM-free Surface}

in Acidic Medium: Electron Tunneling at Play in

Pt/FeNC Hybrid Catalysts for Direct Methanol Fuel Cell

\section{Cathode}

Tomasz Kosmala, ${ }^{1}$ Nicolas Bibent, ${ }^{2}$ Moulay Tahar Sougrati, ${ }^{2}$ Goran Dražić, ${ }^{3}$ Stefano Agnoli, ${ }^{*}$ Frédéric Jaouen $^{2 *}$ and Gaetano Granozzi ${ }^{1}$

1: Department of Chemical Sciences, University of Padua, Via Marzolo 1, 35131 Padova, Italy

2: ICGM, Univ. Montpellier, CNRS, ENSCM, Montpellier, France

3: Department of Materials Chemistry, National Institute of Chemistry, Hajdrihova 19, 1001 Ljubljana, Slovenia

KEYWORDS: hybrid catalyst, core shell, electron tunneling, direct methanol fuel cell, methanol tolerance, model system, $\mathrm{ORR}, \mathrm{Fe}_{2} \mathrm{O}_{3}$

\section{Corresponding Authors}

*frederic.jaouen@umontpellier.fr, stefano.agnoli@unipd.it. 


\section{ABSTRACT}

PGM-free catalysts have high initial activity for $\mathrm{O}_{2}$ reduction reaction, but suffer from low stability in acid medium in PEMFC and DMFC. Here, we shed light on the atomic-scale structure of hybrid Pt/FeNC catalysts (1-2 wt\% of Pt), revealing by STEM and EDXS the presence of Pt@FeO $\mathrm{Farticles.}$ The absence of exposed Pt on the surface is confirmed by the suppression of methanol oxidation reaction and $\mathrm{CO}$ stripping experiments. The promising application of such $\mathrm{Pt} / \mathrm{FeNC}$ catalysts, comprising $\mathrm{FeN}_{\mathrm{x}}$ sites and $\mathrm{Pt} @ \mathrm{FeO}_{\mathrm{x}}$ particles, is demonstrated at the cathode of DMFC. To gain fundamental understanding on the stability in acid medium and on the intrinsic ORR activity of $\mathrm{Pt} @ \mathrm{FeO}_{\mathrm{x}}$, we constructed model surfaces by depositing $\mathrm{FeO}_{\mathrm{x}}$ films with controlled thickness (from 1.0 to $6.4 \mathrm{~nm}$ ), fully covering the $\operatorname{Pt}(111)$ surface, which resulted stable in acid medium in the potential range $0.45-1.05 \mathrm{~V}$ vs. RHE. The specific ORR activity of $\mathrm{Fe}_{2} \mathrm{O}_{3} / \mathrm{Pt}(111)$ increases exponentially with decreasing overlayer thickness, which is explained by the tunneling of Pt electrons through $\mathrm{Fe}_{2} \mathrm{O}_{3}$. This special phenomenon sheds light onto recently reported excellent durability of $\mathrm{Pt} / \mathrm{FeNC}$ composites in PEMFC and identify a promising core@shell strategy leading to stable PGM-free surfaces in acid medium, and tolerant to methanol.

\section{INTRODUCTION}

The electrochemical oxygen reduction reaction (ORR) to water is a key reaction for electrochemical energy conversion devices such as fuel cells and metal-air batteries. ${ }^{1-8}$ A variety of fuel cell (FC) technologies are being developed with operating temperature and chemical environment being defined by the nature of the electrolyte, such as proton exchange membranes (PEM), ${ }^{9}$ anion exchange

membranes (AEM), ${ }^{10,11}$ or solid oxides. Fuel cells based on PEMs (labelled PEMFC when fed with hydrogen, or direct methanol fuel cell, DMFC, when fed with methanol) are more mature than their AEM counterparts and do not suffer from complex issues related to airborne $\mathrm{CO}_{2}$, a challenge for 
alkaline liquid-electrolyte FCs and AEMFCs. ${ }^{12}$ PEMFCs in particular are perceived today as the most promising fuel cells for automotive application, while DMFCs can target niche applications where easiness to handle and fuel storage are important. ${ }^{13-16}$ The first commercial $\mathrm{H}_{2} /$ air PEMFC cars were deployed in 2017 in Japan and USA and contain Pt-based catalysts both at the anode and cathode, with a higher amount of $\mathrm{Pt}$ in the latter. ${ }^{17}$ Despite continuous progress in the ORR activity and durability of platinum-based catalysts for acidic medium, ${ }^{18-21}$ the high cost and low resources of platinum and any platinum-group-metal remain an issue for reaching the final cost targets of fuel cell stacks and also for sustainability reasons. The mining of new platinum and its recycling significantly contribute to $\mathrm{CO}_{2}$ emissions in the life-cycle analysis of PEMFC and DMFC devices. ${ }^{22-24}$ The impact of platinum-groupmetals (PGMs) on the cost and life cycle analysis of DMFCs is stronger than for PEMFCs due to: i) Higher loadings of PGMs at both the anode and cathode of DMFCs compared to PEMFCs; ii) Lower power output per geometric area of membrane electrode assembly of DMFCs $v s$. PEMFCs.

The quest for PGM-free ORR catalysts for PEMFCs and DMFCs has resulted in the demonstration of highly active materials, with FeNC materials comprising atomically dispersed $\mathrm{FeN}_{\mathrm{x}}$ sites currently being the most promising subclass of PGM-free catalysts. ${ }^{25-28}$

While progress is observed in the fundamental understanding of the nature of such active sites and the factors that control their initial activity, ${ }^{29-32}$ slow progress is currently observed regarding the durability in PEMFC and DMFC of FeNC and other PGM-free materials. All FeNC and other Metal-NC catalysts suffer from rapid activity decrease in operating PEMFCs ${ }^{2,33,34}$ and DMFCs. ${ }^{35-38}$ The trend is also observed that the higher is their initial ORR activity, the worse is their durability. ${ }^{2}$ Recent reports indicate that high initial ORR activity for FeNC materials corroborates with high microporous surface area and also with high Fe leaching rates in oxygenated acidic medium. ${ }^{39-41}$ In particular, the simultaneous combination of low electrochemical potential and presence of oxygen seems to trigger Fe demetallation from $\mathrm{FeN}_{\mathrm{x}}$ sites, little or not observed in the absence of $\mathrm{O}_{2} \cdot{ }^{41-43}$ Such demetallation and degradation is likely related to the in situ production of $\mathrm{H}_{2} \mathrm{O}_{2}$ and reactive oxygen species via Fenton 
reactions, catalyzed by Fe cations and other $3 \mathrm{~d}$ transition metal cations. ${ }^{44,45}$ Due to similar acidic environment at the cathode of DMFCs and PEMFCs, it is expected that the degradation rates and mechanisms are similar for FeNC catalysts in both devices. This is supported by recent observations of in situ formation of iron oxide nanoparticles at the cathode of both PEMFC and DMFC, even for FeNC materials that initially contain only $\mathrm{FeN}_{\mathrm{x}}$ sites. ${ }^{37,41}$

Therefore, the identification of rational strategies for improving the durability of PGM-free ORR catalysts in acidic medium is acutely needed. In a recent study, we reported on the stabilization of FeNC by minute amounts of platinum (1-2 wt \%). ${ }^{46}$ The addition of $1-2 \mathrm{wt} \% \mathrm{Pt}$ to a given FeNC catalyst resulted in Pt/FeNC composites with similar ORR activity, but with dramatically improved durability in PEMFC. While the ORR activity of FeNC at $0.8 \mathrm{~V}$ was divided by $c a$ four after PEMFC operation for $50 \mathrm{~h}$ at $0.5 \mathrm{~V}$, no measurable change in ORR activity was observed after functionalization of the same FeNC material with 1-2 wt \% Pt. A longer durability test in PEMFC for $180 \mathrm{~h}$ at $0.5 \mathrm{~V}$ confirmed the improved durability. While Pt particles were observed on the SEM images of the Pt/FeNC composites, the lack of increase in activity towards both the ORR and the electroreduction of $\mathrm{H}_{2} \mathrm{O}_{2}$ for $\mathrm{Pt} / \mathrm{FeNC}$ relative to FeNC clearly indicated that no metallic Pt was present on the top surface. This was corroborated by the lack of CO-stripping signal of the $\mathrm{Pt} / \mathrm{FeNC}$ cathode, both before and after the PEMFC durability test at $0.5 \mathrm{~V}$.

In the present work, two $\mathrm{Pt} / \mathrm{FeNC}$ catalysts were prepared as previously reported, ${ }^{46}$ and further investigated with ${ }^{57} \mathrm{Fe}$ Mössbauer spectroscopy at $5 \mathrm{~K}$ and scanning transmission electron microscopy (STEM) coupled with energy-dispersive X-ray spectroscopy (EDXS). They were also electrochemically characterized for ORR catalysis with a rotating disk electrode (RDE) in the presence of methanol, as well as at the cathode of DMFC. The STEM-EDXS results show that both large and small Pt particles in these $\mathrm{Pt} / \mathrm{FeNC}$ hybrid catalysts are covered with a thin shell rich in $\mathrm{Fe}$ and $\mathrm{O}$, while ${ }^{57} \mathrm{Fe}$ Mössbauer spectroscopy at $5 \mathrm{~K}$ reveals the presence of ferric oxide, which is absent in the reference FeNC material. The electrochemical results identify the complete tolerance to methanol of these $\mathrm{Pt} / \mathrm{FeNC}$ powder 
catalysts. DMFC results with Pt/FeNC cathodes comprising only $40-80 \mu \mathrm{g}_{\mathrm{Pt}} \mathrm{cm}^{-2}$ (4 mg total mass of $\mathrm{Pt} / \mathrm{FeNC}$ per $\mathrm{cm}^{2}$ ) showed promising power performance compared to state-of-art $\mathrm{Pt} / \mathrm{C}$ cathodes with $2000 \mu \mathrm{g}_{\mathrm{Pt}} \mathrm{cm}^{-2}$, advantageously allowing the utilization of high methanol concentration at the anode without any drawback. In order to better understand the stability and possible activity of $\mathrm{Pt} @ \mathrm{FeO}_{\mathrm{x}}$ coreshell particles, electrochemical studies were then performed in acidic electrolyte on model surfaces prepared via the deposition of ultrathin films of $\mathrm{Fe}_{2} \mathrm{O}_{3}$ on $\mathrm{Pt}(111)$. These studies revealed unexpected stability in acidic medium in the region $0.45-1.05 \mathrm{~V} v s$. RHE and moderate ORR activity when the Fe oxide layer is $\leq 3.2 \mathrm{~nm}$. The ORR activity of $\mathrm{Fe}_{2} \mathrm{O}_{3}$ layers on $\mathrm{Pt}(111)$ was negatively correlated with layer thickness, which can be explained by electron tunneling effect from the core through the shell. The insights gained from model surfaces of $\mathrm{Fe}_{2} \mathrm{O}_{3}$ layers on $\mathrm{Pt}(111)$ and advanced characterization of the present Pt/FeNC hybrid materials explain well the methanol tolerance and lack of CO stripping signal of the latter. Overall, these insights can trigger novel approaches for the design of PGM-free or PGMbased catalysts for ORR and HOR by changing the nature of the metal, either in the core or in the shell, with tuned selectivity and tolerance to a range of fuels and chemicals.

\section{EXPERIMENTAL SECTION}

Pt/FeNC powder catalysts synthesis: $\mathrm{Fe}_{1.0} \mathrm{~d}$ was synthesized from $\mathrm{ZIF}-8$, a $\mathrm{Zn}$ (II) zeolitic imidazolate framework (Basolite Z1200 from BASF), Fe(II) acetate and 1,10-phenanthroline (phen). 800 mg of ZIF8, $200 \mathrm{mg}$ of phen and $31.5 \mathrm{mg}$ of $\mathrm{Fe}(\mathrm{II})$ acetate were poured into a $\mathrm{ZrO}_{2}$ crucible together with 100 $\mathrm{ZrO}_{2}$ balls ( $5 \mathrm{~mm}$ diameter), defining a content of $1 \mathrm{wt} \% \mathrm{Fe}$ in the catalyst precursor. After being sealed in ambient atmosphere, the crucible was subjected to 4 cycles of $30 \mathrm{~min}$ ballmilling at $400 \mathrm{rpm}$ (Fritsch Pulverisette 7 premium). The resulting catalyst precursor was flash-pyrolyzed at $1050^{\circ} \mathrm{C}$ in $\mathrm{Ar}$ for $1 \mathrm{~h}$. Then $300 \mathrm{mg}$ of $\mathrm{Fe}_{1.0} \mathrm{~d}$ was impregnated with $550 \mu \mathrm{L}$ (stepwise, $100 \mu \mathrm{L}$ at a time with grinding for each addition) of an aqueous solution of $\mathrm{Pt}\left(\mathrm{NH}_{3}\right)_{4} \mathrm{Cl}_{2} \cdot \mathrm{H}_{2} \mathrm{O}$. The concentration of the $\mathrm{Pt}$ salt solution was adjusted in order to reach 1.0 or $2.0 \mathrm{wt} \% \mathrm{Pt}$ in the hybrid catalysts $(9.9$ and $17.9 \mathrm{mg} / \mathrm{mL}$ for 1 and $2 \mathrm{wt}$ 
$\% \mathrm{Pt}$, respectively). The impregnated sample was then dried for $2 \mathrm{~h}$ in an oven at $80^{\circ} \mathrm{C}$ under air. The dry powder was loaded in a quartz boat, itself in a quartz tube and ramp-heated under $\mathrm{N}_{2}$ flow from 300 to $560^{\circ} \mathrm{C}$ at a rate of $4^{\circ} \mathrm{C}$ per minute. The gas flow was then switched from $\mathrm{N}_{2}$ to $5 \% \mathrm{H}_{2}$ in $\mathrm{N}_{2}$ for $2 \mathrm{~h}$ at $560^{\circ} \mathrm{C}$. After that, the split hinge oven was opened and the tube removed from it and let to cool down naturally under $\mathrm{N}_{2}$ flow. The resulting catalysts are labelled $\mathrm{Pt}_{1.0} \mathrm{Fe}_{1.0} \mathrm{~d}$ and $\mathrm{Pt}_{2.0} \mathrm{Fe}_{1.0} \mathrm{~d}$, for 1 and 2 wt $\%$ Pt added onto $\mathrm{Fe}_{1.0} \mathrm{~d}$, respectively.

STEM/EDXS characterization of $\boldsymbol{P t}_{2.0} \mathrm{Fe}_{1.0}$ : Probe Cs-corrected scanning transmission electron microscope Jeol ARM 200 F, equipped with a cold field emission electron source, was used for imaging $\mathrm{Pt}_{2.0} \mathrm{Fe}_{1.0} \mathrm{~d}$, and in particular for imaging the Pt nanoparticles. To minimize the beam damage, $80 \mathrm{keV}$ and low beam current were used. High-angle annular dark-field (HAADF) images were obtained using 68-180 mrad collection half-angles at $24 \mathrm{mrad}$ probe convergence semi-angle. Images were filtered with a non-linear filter, which is a combination of low-pass and Wiener filters.

${ }^{57}$ Fe Mössbauer spectroscopy characterization of $\boldsymbol{P t}_{2.0} \boldsymbol{F e}_{1.0}$ : The ${ }^{57} \mathrm{Fe}$ Mössbauer spectrometer (Wissel, Germany) was operated in transmission mode with a ${ }^{57} \mathrm{Co}: \mathrm{Rh}$ source. The velocity driver was operated in constant acceleration mode with a triangular velocity waveform. The velocity scale was calibrated with the magnetically split sextet of a high-purity $\alpha$-Fe foil at room temperature. The spectra were fitted to appropriate combinations of Lorentzian profiles representing quadrupole doublets, sextets by least-squares methods. Isomer shift values are reported relative to $\alpha$-Fe at room temperature. The powder catalyst was mounted in a $2 \mathrm{~cm}^{2}$ holder. Mössbauer measurements at $5 \mathrm{~K}$ was performed in a helium flow cryostat (SHI-850 Series from Janis, USA).

Electrochemical characterization in $R D E$ of $\boldsymbol{P t}_{2.0} F_{e_{1.0}}$ : We used a Pine MSR Electrode Rotator with a RDE/RRDE precision shaft and glassy carbon tip. The ink with $10 \mathrm{mg}$ catalyst, $108.4 \mu \mathrm{L}$ Nafion solution (5wt \%, Sigma Aldrich), $300 \mu \mathrm{L}$ ethanol and $36.5 \mu \mathrm{L}$ ultrapure water $(>18 \mathrm{M} \Omega$ ) was prepared. The ink was ultrasonicated for $30 \mathrm{~min}$. Then, $7 \mu \mathrm{L}$ was deposited onto a glassy carbon disk with a diameter of $5 \mathrm{~mm}$ leading to a total catalyst loading of $0.8 \mathrm{mg} \mathrm{cm}^{-2}$. The electrodes were then immersed into $0.1 \mathrm{M} \mathrm{HClO}_{4}$ in a glass cell with graphite as counter electrode, and a platinum wire in a separate 
compartment, saturated with $\mathrm{H}_{2}$, acting as a reversible hydrogen electrode (RHE). The rotation rate was $1600 \mathrm{rpm}$. For break-in, at least 5 cyclic voltammogramms (CVs) were applied between 0.0 and 1.0 $\mathrm{V}_{\mathrm{RHE}}$ at $10 \mathrm{mV} \mathrm{s}^{-1}$ in $\mathrm{N}_{2}$-saturated electrolyte. If the last two scans did not superimpose, more CVs were applied. Subsequently, CVs were recorded at $1 \mathrm{mV} \mathrm{s}^{-1}$ in $\mathrm{O}_{2}$ saturated electrolyte between 0.1 and 1.0 $V_{R H E}$, a scan rate sufficiently low to neglect capacitive currents.

DMFC experiments: The anode was a gas diffusion electrode already catalyzed with PtRu/C (2000 $\mu g_{\text {PtRu }} \mathrm{cm}^{-2}$, SIGRACET S10BC). The cathode was either a gas diffusion electrode already catalyzed with Pt/C (2000 $\mu \mathrm{g}_{\mathrm{Pt}} \mathrm{cm}^{-2}$, SIGRACET S10BC) or a Fe-N-C cathode obtained by depositing $4.0 \mathrm{mg} \mathrm{cm}^{-}$ ${ }^{2}$ of Pt/FeNC from an ink on a gas diffusion electrode (SIGRACET S29BC), resulting in 40 and $80 \mu \mathrm{g}_{\mathrm{Pt}}$ $\mathrm{cm}^{-2}$ with $\mathrm{Pt}_{1.0} \mathrm{Fe}_{1.0} \mathrm{~d}$ and $\mathrm{Pt}_{2.0} \mathrm{Fe}_{1.0} \mathrm{~d}$, respectively. The ink was prepared by sonicating for 1 hour 103.2 mg of catalyst, $3.364 \mathrm{~mL}$ of $5 \mathrm{wt}$ \% Nafion solution (in lower aliphatic alcohols and $15 \mathrm{wt}$ \% water), $1.682 \mathrm{~mL}$ 1-propanol, and $1.403 \mathrm{~mL}$ deionized water. The catalyst ink was drop cast in 3 aliquots onto the $25 \mathrm{~cm}^{2}$ gas diffusion layer, giving a total (all elements) loading of $4 \mathrm{mg} \cdot \mathrm{cm}^{-2}$, then dried at $70{ }^{\circ} \mathrm{C}$ for 1 hour. The cathode was hot-pressed onto Nafion 117 with the commercial anode using a pressure of 2 tons and $135{ }^{\circ} \mathrm{C}$ for 2 minutes. The cell assembly consisted of a Fuel Cell Technologies Inc. single cell with serpentine flow fields in graphite end plates. The methanol flow rate was $50 \mathrm{~mL} \mathrm{~min}^{-1}$. The cell temperature, cathode flow rate and absolute pressure were i) $80^{\circ} \mathrm{C}, 1 \mathrm{bar}, 400 \mathrm{~mL} \mathrm{~min}^{-1}$ or ii) $90^{\circ} \mathrm{C}, 1.5$ bar, $600 \mathrm{~mL} \mathrm{~min}^{-1}$ or iii) $100^{\circ} \mathrm{C}, 2$ bars, $600 \mathrm{~mL} \mathrm{~min}^{-1}$. Polarisation curves were recorded point by point under galvanostatic control, from low to high current densities and then vice versa. For each current density, the cell voltage obtained when increasing the current and then decreasing it was averaged. This average is used to report the polarisation curves.

Preparation of $\alpha-\mathrm{Fe}_{2} \mathrm{O}_{3} / \mathbf{P t}(111)$ surfaces: The $\alpha-\mathrm{Fe}_{2} \mathrm{O}_{3}$ on $\mathrm{Pt}(111)$ surface was prepared by adopting the procedures described in Refs. ${ }^{47,48}$. The surface of the Pt(111) single crystal (MaTeck) was cleaned by cycles of sputtering $\left(1.5 \mathrm{keV}, 10^{-6}\right.$ mbar of Ar, room temperature) and annealing at $1000 \mathrm{~K}$. The residual carbon was removed by annealing in $2.0 \cdot 10^{-7}$ mbar of oxygen at $900 \mathrm{~K}$ and, subsequently, the adsorbed oxygen was removed by flash annealing at $1000 \mathrm{~K}$. This procedure was repeated until the 
LEED pattern of a clean $\operatorname{Pt}(111)$ surface with sharp spots and low background was obtained. The Fe oxide films were grown by repeated cycles of reactive evaporation of Fe onto the clean $\mathrm{Pt}(111)$ substrate at $2 \cdot 10^{-5} \mathrm{mbar}_{2}$ partial pressure and keeping the substrate at $800 \mathrm{~K}$. Then, the sample was annealed at $1050 \mathrm{~K}$ at $4 \cdot 10^{-3}$ mbar $\mathrm{O}_{2}$ to fully convert the $\mathrm{Fe}$ oxide phases to $\alpha-\mathrm{Fe}_{2} \mathrm{O}_{3}$. Oxygen was introduced in the preparation chamber by means of a capillary located at only $\mathrm{ca} 1 \mathrm{~cm}$ from the sample.

Structural characterization of $\alpha-\mathrm{Fe}_{2} \mathrm{O}_{3} / \mathrm{Pt}(111)$ surfaces: The composition of the samples and the chemical changes induced by the exposure to the EC environment were investigated by XPS using an EA 125 Omicron electron analyzer equipped with five channeltrons, working at a base pressure of $2 \cdot 10^{-}$ ${ }^{10}$ mbar. The XPS data were collected at RT with the $\mathrm{Mg} \mathrm{K \alpha}$ line $(\mathrm{h} v=1253.6 \mathrm{eV})$ of a nonmonochromatic dual-anode DAR400 X-ray source using $0.1 \mathrm{eV}$ energy step, $0.5 \mathrm{~s}$ collection time and $20 \mathrm{eV}$ pass energy. The binding energy (BE) scale was calibrated using a gold sample (Au $4 \mathrm{f}$ at $84 \mathrm{eV}$ ). The film thickness was determined before and after the electrochemical treatments by angle-resolved XPS (AR-XPS) measurements using the $\mathrm{Fe}_{2 p}$ and $\mathrm{Pt}_{4 \mathrm{f}}$ photoemission peak intensity, according to the method reported in Ref. ${ }^{49}$. Low energy electron diffraction (LEED) patterns were acquired using an incident electron beam with energy between 30 and $80 \mathrm{eV}$. All LEED patterns were recorded at room temperature.

Electrochemical studies on $\alpha-\mathrm{Fe}_{2} \mathrm{O}_{3} / \mathrm{Pt}(111)$ surfaces: Cyclic voltammetry (CV) and methanol tolerance of $\alpha-\mathrm{Fe}_{2} \mathrm{O}_{3} / \mathrm{Pt}(111) \mathrm{UT}$ films were investigated in a conventional ex situ three-electrode cell. A glassy carbon rod was used as counter electrode and a saturated calomel electrode (SCE) as reference electrode. All potentials reported are however referred to the reversible hydrogen electrode (RHE) scale, and the conversion was done according to the equation: $\mathrm{E}(\mathrm{RHE})=\mathrm{E}(\mathrm{SCE})+0.258+0.059 \times \mathrm{pH}$. A custom-designed sample holder with an area of $0.502 \mathrm{~cm}^{2}$ was used.

\section{In Situ Electrochemical Scanning Tunneling Microscopy (EC-STM) studies on $\alpha-\mathrm{Fe}_{2} \mathrm{O}_{3} / \mathrm{Pt}(111)$} surfaces: The in situ EC-STM measurements were carried out using a home-built EC-STM at constant current mode, as described by Wilms et al. ${ }^{50}$. The tunneling tips were electrochemically etched from a $0.25 \mathrm{~mm}$ tungsten wire in $2 \mathrm{M} \mathrm{KOH}$ solution and, subsequently, cleaned in high purity water, dried and 
coated by passing the tip through a drop of hot glue. Platinum wires were used as counter and reference electrodes. The Pt reference electrode was calibrated vs. SCE in Ar-saturated 0.1 $\mathrm{M} \mathrm{HClO}_{4}$. The image analysis was carried out using the software WSxM 5.0.

\section{RESULTS AND DISCUSSION}

Two hybrid catalysts labelled $\mathrm{Pt}_{1.0} \mathrm{Fe}_{1.0}$ d and $\mathrm{Pt}_{2.0} \mathrm{Fe}_{1.0}$ d were synthesized as previously reported. ${ }^{46}$ The synthesis involves first the preparation of an $\mathrm{Fe}-\mathrm{N}-\mathrm{C}$ catalyst, $\mathrm{Fe}_{1.0} \mathrm{~d}$, with 1.0 standing for $1 \mathrm{wt} \% \mathrm{Fe}$ before pyrolysis and $\mathrm{d}$ for dry ball milling. $\mathrm{Fe}_{1.0} \mathrm{~d}$ was then impregnated by given amounts of a $\mathrm{Pt}$ salt to result in 1.0 or $2.0 \mathrm{wt} \% \mathrm{Pt}$ in the hybrid catalyst, then dried and annealed at $560^{\circ} \mathrm{C}$ in $5 \% \mathrm{H}_{2}$ in $\mathrm{N}_{2}$ (see Methods). While $\mathrm{Pt}_{1.0} \mathrm{Fe}_{1.0} \mathrm{~d}$ and $\mathrm{Pt}_{2.0} \mathrm{Fe}_{1.0} \mathrm{~d}$ were demonstrated to be free of metallic platinum on their surface and they achieved at best only $1 / 50^{\text {th }}$ the ORR-activity of $\mathrm{Pt} / \mathrm{C},{ }^{46}$ the yet unknown structure and reactivity of Pt in such materials precludes any a priori statement on their tolerance to methanol while catalyzing the ORR. Figure 1a shows no significant difference in the ORR polarisation curves measured for $\mathrm{Pt}_{1.0} \mathrm{Fe}_{1.0} \mathrm{~d}$ in acid in the absence of methanol and after addition of 0.1 or $2.0 \mathrm{M}$ methanol. This clearly indicates that both $\mathrm{Pt}$ in $\mathrm{Pt}_{1.0} \mathrm{Fe}_{1.0} \mathrm{~d}$ and the Fe-based actives sites in $\mathrm{Pt}_{1.0} \mathrm{Fe}_{1.0} \mathrm{~d}$ are inactive towards methanol oxidation up to $1.0 \mathrm{~V}$ vs. a reversible hydrogen electrode (RHE). For Fe-based active sites, this comes to no surprise since all other FeNC catalysts previously studied to that end showed complete methanol tolerance. ${ }^{51,52}$ In contrast, the methanol tolerance of Pt here is different from the well-known methanol electro-oxidation activity of state-of-art $\mathrm{Pt} / \mathrm{C}$, when metallic $\mathrm{Pt}$ is exposed to the surface. ${ }^{53,54}$ The present hybrid $\mathrm{Pt} / \mathrm{FeNC}$ catalysts are therefore promising for application at the cathode of DMFC, being tolerant to methanol crossover from the anode to the cathode and much more durable than FeNC alone, as previously shown in PEMFC. ${ }^{46} \mathrm{Pt}_{1.0} \mathrm{Fe}_{1.0} \mathrm{~d}$ and $\mathrm{Pt}_{2.0} \mathrm{Fe}_{1.0} \mathrm{~d}$ were therefore evaluated at the cathode of DMFC. 

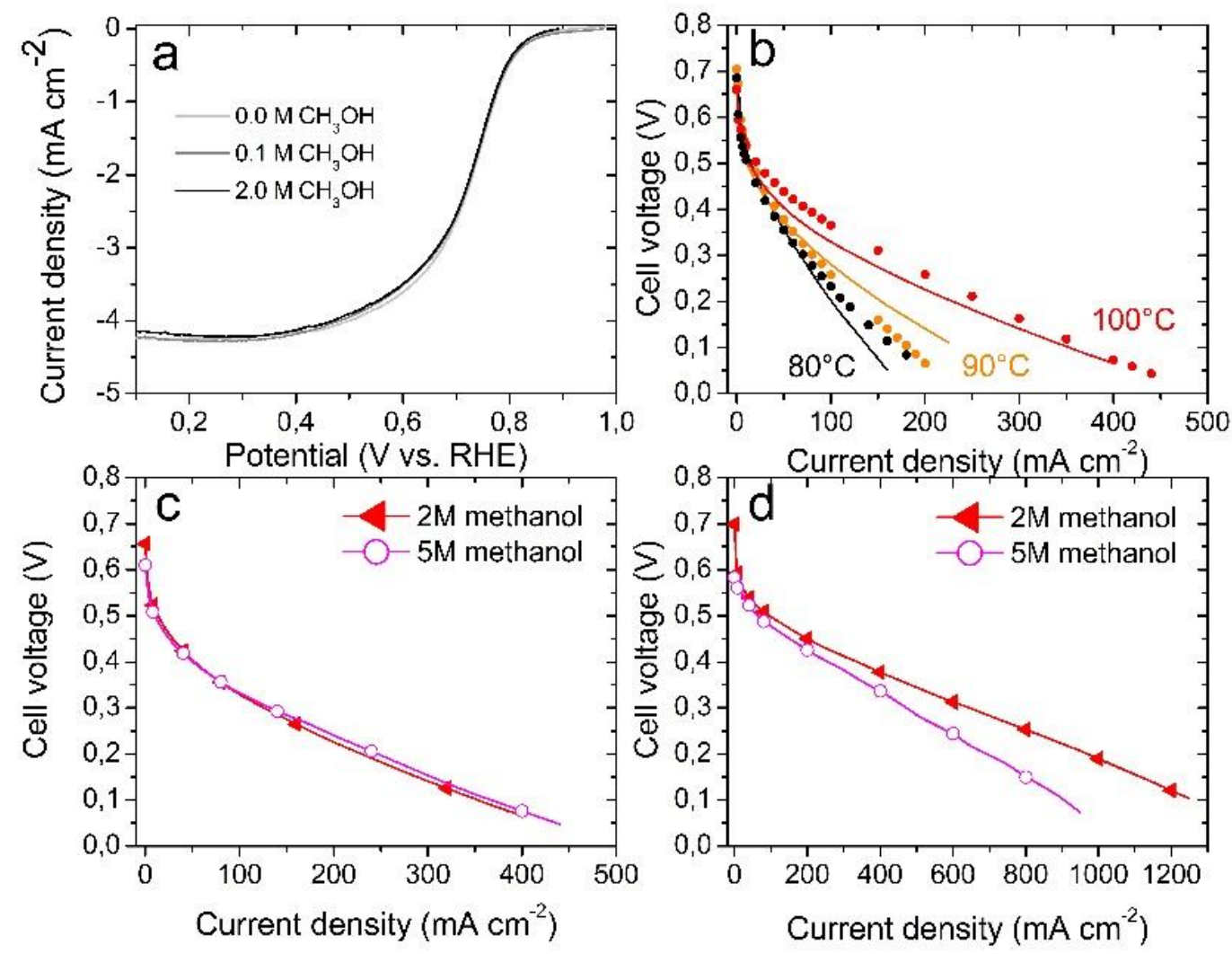

Figure 1. Electrochemical characterisation of hybrid $\mathrm{Pt} / \mathrm{FeNC}$ catalysts and comparison to a commercial $\mathrm{Pt} / \mathrm{C}$ cathode. a) Effect of methanol concentration in $0.1 \mathrm{M} \mathrm{HClO}_{4}$ on $\mathrm{ORR}$ polarisation curves measured in $\mathrm{RDE}$ for $\mathrm{Pt}_{1.0} \mathrm{Fe}_{1.0} \mathrm{~d}$ at a loading of $0.8 \mathrm{mg} \mathrm{cm}{ }^{-2}\left(8 \mu \mathrm{gtt}_{\mathrm{Pt}} \mathrm{cm}^{-2}\right)$. b) DMFC polarisation curves at 80,90 or $100^{\circ} \mathrm{C}$ with cathodes based on $\mathrm{Pt}_{1.0} \mathrm{Fe}_{1.0} \mathrm{~d}$ (circles) or $\mathrm{Pt}_{2.0} \mathrm{Fe}_{1.0} \mathrm{~d}$ (solid curves) at a total cathode catalyst loading of $4 \mathrm{mg} \cdot \mathrm{cm}^{-2}$ (40 and $80 \mu \mathrm{g}_{\mathrm{Pt}} \mathrm{cm}^{-2}$ with $\mathrm{Pt}_{1.0} \mathrm{Fe}_{1.0} \mathrm{~d}$ and $\mathrm{Pt}_{2.0} \mathrm{Fe}_{1.0} \mathrm{~d}$, respectively). c) Effect of methanol concentration on the DMFC polarisation curves at $100^{\circ} \mathrm{C}$ with a $\mathrm{Pt}_{2.0} \mathrm{Fe}_{1.0} \mathrm{~d}$ cathode at a total cathode catalyst loading of $4 \mathrm{mg} \cdot \mathrm{cm}^{-2}\left(80 \mu \mathrm{g}_{\mathrm{Pt}} \mathrm{cm}^{-2}\right.$. d) Effect of methanol concentration on the DMFC polarisation curves at $100^{\circ} \mathrm{C}$ with a commercial $\mathrm{Pt} / \mathrm{C}$ cathode $(2000$ $\mu g_{\mathrm{Pt}} \cdot \mathrm{cm}^{-2}$ ). For a), the rotation rate was $1600 \mathrm{rpm}$. For all DMFC measurements, the anode was PtRu/C $\left(2 \mathrm{mg}_{\mathrm{PtRu}} \mathrm{cm}^{-2}\right)$, the membrane was Nafion 117. For b), the cell temperature was 80,90 or $100^{\circ} \mathrm{C}$ and the methanol concentration was $2.0 \mathrm{M}$. For c) and d), the methanol concentration was 2.0 or $5.0 \mathrm{M}$ and the cell temperature was $100^{\circ} \mathrm{C}$. 
The effect of cell temperature was first investigated, highlighting strong improvement from 80 to $100^{\circ} \mathrm{C}$

(Figure 1b). The cell performance obtained with $\mathrm{Pt}_{1.0} \mathrm{Fe}_{1.0} \mathrm{~d}$ and $\mathrm{Pt}_{2.0} \mathrm{Fe}_{1.0} \mathrm{~d}$ is comparable, the difference lying within the reproducibility error. In particular, the cell performance at high voltage (kinetically controlled region) is very similar for both cathode catalysts, as expected from our previous work. ${ }^{46}$ Since the content of $1 \mathrm{wt} \% \mathrm{Pt}$ was shown in PEMFC to be the lower-end limit for complete durability over at least $50 \mathrm{~h}$ in PEMFC, ${ }^{46}$ we then focused the DMFC measurements on the $\mathrm{Pt}_{2.0} \mathrm{Fe}_{1.0} \mathrm{~d}$ cathode. The latter showed complete durability for all the $50 \mathrm{~h}$ PEMFC tests performed at our laboratory and for different batches of $\mathrm{Pt}_{2.0} \mathrm{Fe}_{1.0} \mathrm{~d}$. The effect of methanol concentration at the anode feed was then investigated, and the results confirm the methanol tolerance observed in RDE, with unnoticeable change from 2 to $5 \mathrm{M}$ feed (Figure 1c). For comparison, the same measurements were performed with a commercial $\mathrm{Pt} / \mathrm{C}$ cathode with high Pt loading, and the results show an important decrease of cell performance from 2 to $5 \mathrm{M}$ methanol feed (Figure 1d). The effect would be even more significant for lower Pt loadings in $\mathrm{Pt} / \mathrm{C}$ cathodes, due to enhanced $\mathrm{CO}$ poisoning on regular Pt particles with surfaceexposed Pt. This operando poisoning limits the methanol concentration that can be used in DMFC systems, with a strong impact on the footprint of the methanol reservoir and implies high cathode Pt loadings. The $\mathrm{Pt}_{2.0} \mathrm{Fe}_{1.0} \mathrm{~d}$ cathode is therefore promising to overcome those limitations. The current density at $0.3 \mathrm{~V}$ and $100^{\circ} \mathrm{C}$ with $5 \mathrm{M}$ methanol feed is about $110 \mathrm{~mA} \mathrm{~cm}$ with the $\mathrm{Pt}_{2.0} \mathrm{Fe}_{1.0} \mathrm{~d}_{\text {cathode }}$ $\left(80 \mu \mathrm{g}_{\mathrm{Pt}} \mathrm{cm}^{-2}\right)$, ca $25 \%$ of the current density reached in the same conditions with the commercial $\mathrm{Pt} / \mathrm{C}$ cathode (2000 $\mu \mathrm{g}_{\mathrm{Pt}} \mathrm{cm}^{-2}$ ) (Figure 1c-d, magenta curves). While the absolute performance is presently lower, due to lower ORR kinetics, a high margin exists to approach the same performance. This might be achieved for example by increasing the Pt content on FeNC, if such Pt structures have moderate ORR activity. Alternatively, it might be achieved by increasing the ORR activity of the FeNC substrate. In the former approach, the increased content of Pt should however be carried out by design, leading to the synthesis of methanol-tolerant Pt structures.

The structure of $\mathrm{Pt}_{2.0} \mathrm{Fe}_{1.0} \mathrm{~d}$ was then investigated with STEM-EDXS in order to better understand the structure of the Pt particles and why they are inactive toward methanol oxidation. In our original paper 
on hybrid $\mathrm{Pt} / \mathrm{FeNC}$ catalysts, ${ }^{46}$ the distribution of Pt particles on the Fe- and N-doped carbon support of $\mathrm{Pt}_{1.0} \mathrm{Fe}_{1.0} \mathrm{~d}$ was revealed by STEM (Figure 2 and Figure S1 in Ref. ${ }^{46}$ ). Elemental mapping with EDXS on a catalyst area comprising both the FeNC background and particles expected to be Pt-rich confirmed the strong presence of Pt, but no information on the element distribution inside the particle could be obtained due to limits intrinsic to the microscope (Figure S1 in Ref. ${ }^{46}$ ). Here, a STEM image of a large area of $\mathrm{Pt}_{2.0} \mathrm{Fe}_{1.0} \mathrm{~d}$ shows again large and small bright particles (Figure S1a). These particles are identified by EDXS to be Pt-rich (Figure S1b). EDXS mapping on Fe identifies both a diffuse background signal related to $\mathrm{Fe}$ that is atomically dispersed in the support $\left(\mathrm{Fe}_{1.0} \mathrm{~d}\right)$ but also a localized Fe signal matching with the position of the Pt-rich particles (Figure S1b-c). While this could be interpreted as the presence of PtFe alloy particles, EDXS mapping on oxygen reveals an even better match between $\mathrm{Fe}$ and $\mathrm{O}$ than between $\mathrm{Fe}$ and $\mathrm{Pt}$ (Figure S1c-d), suggesting that $\mathrm{Fe}$ and $\mathrm{O}$ are intimately organized. The overlay between the Pt and $\mathrm{Fe}$ signals further suggests $\mathrm{Pt} @ \mathrm{FeO}_{\mathrm{x}}$ core-shell structures (Figure S1e). Higher resolution STEM and EDXS mapping on a single Pt particle further support this view (Figure 2). The high-angle annular dark-field (HAADF), bright field STEM images (Figure 2a-b), EDXS mapping on Pt, $\mathrm{Fe}, \mathrm{O}$ and the overlay of the signals for $\mathrm{Pt}$ and $\mathrm{Fe}$ (Figure 2c) identify a Pt core of $c a 7.5 \mathrm{~nm}$ and a Fe-oxide shell of $c a 1.2-1.3 \mathrm{~nm}$. The elemental profile lines in Figure 2d further identify the $\mathrm{Fe}$ and $\mathrm{O}$ shell, extending beyond the Pt core. This $\mathrm{Pt} @ \mathrm{FeO}_{\mathrm{x}}$ structure was observed on large and small particles. Figure $\mathbf{S 2}$ shows another Pt particle with a different shape and size than that in Figure 2, but having a similar thickness of the $\mathrm{FeO}_{\mathrm{x}}$ shell, ca $1.3 \mathrm{~nm}$. 


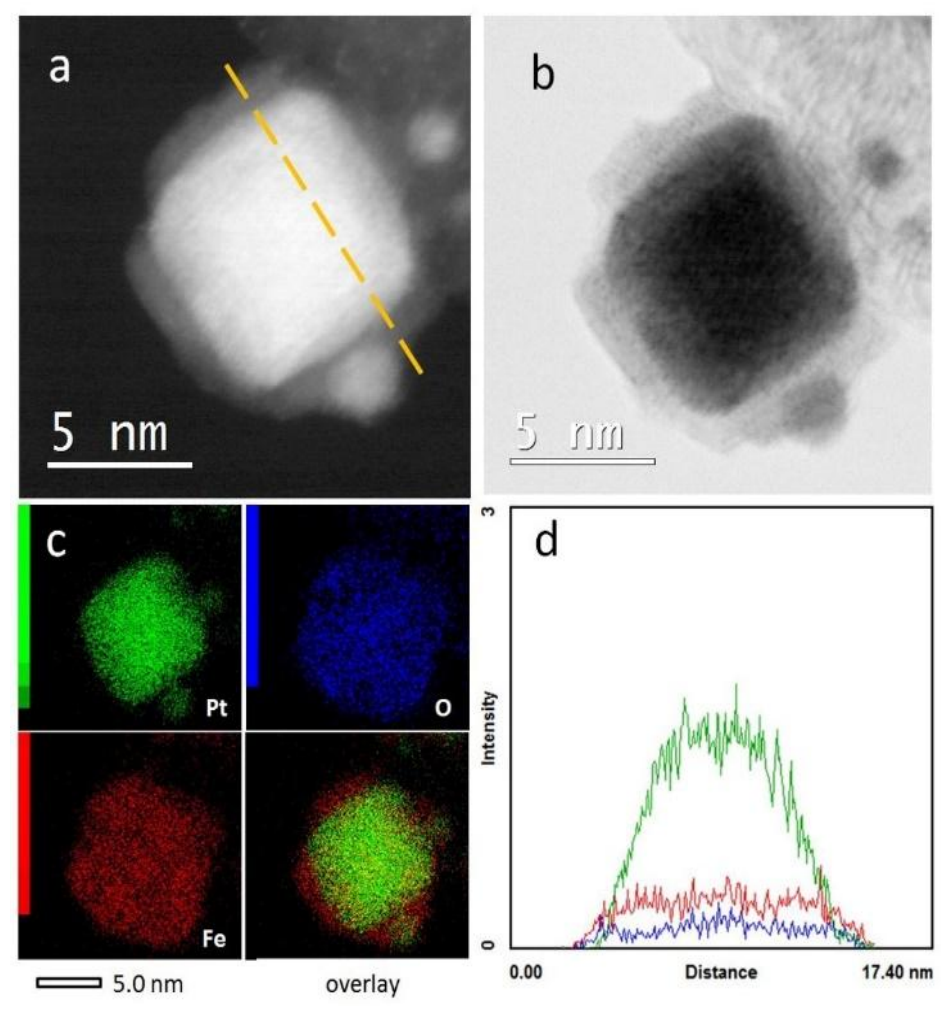

Figure 2. STEM-EDXS characterization of a single Pt-rich particle in $\mathrm{Pt}_{2.0} \mathrm{Fe}_{1.0} \mathrm{~d}$. a) HAADF and b) bright field images, c) EDXS elemental mapping for Pt (green), iron (red), oxygen (blue) and overlay Pt and $\mathrm{Fe}$ (lower left hand side corner), d) intensity profiles of the various elements along the line indicated in a).

$\mathrm{Pt}_{2.0} \mathrm{Fe}_{1.0} \mathrm{~d}$ was then characterized with ${ }^{57} \mathrm{Fe}$ Mössbauer spectroscopy at $5 \mathrm{~K}$. The importance of performing ${ }^{57} \mathrm{Fe}$ Mössbauer spectroscopy at low temperature for characterizing FeNC materials was recently put forth in several reports. ${ }^{31,32}$ Measurements above $c a 60 \mathrm{~K}$ lead to an ambiguous quadrupole doublet signal with low quadrupole splitting value $\left(c a 1 \mathrm{~mm} \mathrm{~s}^{-1}\right)$, that may be assigned either to specific $\mathrm{FeN}_{4}$ sites or to nanometric Fe oxide particles. At $5 \mathrm{~K}$, the latter usually become paramagnetic, leading to a sextet spectral component while $\mathrm{FeN}_{4}$ sites still result in a doublet component. ${ }^{55}$ The spectrum of $\mathrm{Pt}_{2.0} \mathrm{Fe}_{1.0} \mathrm{~d}$ (Figure S3 and Table S1) comprises a number of components that had previously been observed by us in the room-temperature spectrum of $\mathrm{H}_{2}-\mathrm{Fe}_{1.0} \mathrm{~d}$ (Figure $3 \mathrm{~b}$ in Ref ${ }^{46}$ ). The latter is the reference material, obtained after subjecting $\mathrm{Fe}_{1.0} \mathrm{~d}$ to the same annealing treatment in $5 \% \mathrm{H}_{2} / \mathrm{N}_{2}$ at $560^{\circ} \mathrm{C}$ as applied to prepare $\mathrm{Pt} / \mathrm{FeNC}$ hybrids from $\mathrm{Fe}_{1.0} \mathrm{~d}$ in the present work. The ${ }^{57} \mathrm{Fe}$ Mössbauer 
spectrum of $\mathrm{Pt}_{2.0} \mathrm{Fe}_{1.0} \mathrm{~d}$ comprises two quadrupole doublets D1, D2 assigned to atomically dispersed $\mathrm{FeN}_{4}$ moieties of different spin and oxidation states (from DFT-calculated quadrupole splitting values and experimental spectroscopic characterisations of a model Fe-N-C catalyst, D1 was identified to be mainly a $\mathrm{Fe}(\mathrm{III}) \mathrm{N}_{4} \mathrm{C}_{12}$ single-metal-atom site in high-spin state and $\mathrm{D} 2$ a $\mathrm{Fe}(\mathrm{II}) \mathrm{N}_{4} \mathrm{C}_{10}$ single-metal-atom site in low- or medium-spin state), ${ }^{31}$ a singlet assigned to $\gamma$-Fe and a sextet assigned to $\alpha$-Fe. However, one additional sextet component (accounting for $16 \%$ of the signal, Table S1) is observed in the ${ }^{57} \mathrm{Fe}$ Mössbauer spectrum of $\mathrm{Pt}_{2.0} \mathrm{Fe}_{1.0} \mathrm{~d}$ at $5 \mathrm{~K}$ that is absent in the room-temperature spectrum of $\mathrm{H}_{2}-\mathrm{Fe}_{1.0} \mathrm{~d}$, and unambiguously assigned to high-spin ferric oxide, most probably $\mathrm{Fe}_{2} \mathrm{O}_{3}$. This component fits well with the observation by STEM-EDXS of a nanometric Fe-oxide shell around Pt nanoparticles in $\mathrm{Pt}_{2.0} \mathrm{Fe}_{1.0} \mathrm{~d}$.

These high resolution STEM-EDXS and low-temperature ${ }^{57} \mathrm{Fe}$ Mössbauer spectroscopy characterizations of $\mathrm{Pt}_{2.0} \mathrm{Fe}_{1.0} \mathrm{~d}$ therefore suggest that a fraction of $\mathrm{Fe}$ from $\mathrm{H}_{2}-\mathrm{Fe}_{1.0} \mathrm{~d}$ migrated on the surface during the reductive annealing of the Pt salt impregnated on $\mathrm{H}_{2}-\mathrm{Fe}_{1.0} \mathrm{~d}$, leading to the $\mathrm{Pt} @ \mathrm{FeO}_{\mathrm{x}}$ structures supported on the Fe- and N-doped carbon substrate. These novel insights explain i) why the addition of $1-2 \mathrm{wt} \% \mathrm{Pt}$ to $\mathrm{H}_{2}-\mathrm{Fe}_{1.0} \mathrm{~d}$ followed by the present annealing treatment did not lead to significant increase in the initial ORR activity relative to $\mathrm{H}_{2}-\mathrm{Fe}_{1.0} \mathrm{~d}$, and ii) why no $\mathrm{CO}$ stripping signal was observed for $\mathrm{Pt}_{1.0} \mathrm{Fe}_{1.0} \mathrm{~d} .{ }^{46}$ While the addition of $1-2 \mathrm{wt} \% \mathrm{Pt}$ to $\mathrm{H}_{2}-\mathrm{Fe}_{1.0} \mathrm{~d}$ did not lead to an ORRactivity increase, it resulted in a spectacular stabilization during operation in PEMFC with almost no performance loss at $0.5 \mathrm{~V}$ and almost no activity increase or decrease at $0.8 \mathrm{~V}$, even after $180 \mathrm{~h}$ operation (Figure 10 in Ref. ${ }^{46}$ ). This must imply that the Pt particles remained covered by the iron oxide shell in operando, in spite of the expected leaching of ferric oxide as ferrous cations at e.g. $0.5 \mathrm{~V}$ in the acidic medium of PEMFCs. We assign the stability of ferric oxide on metallic Pt nanoparticles to a strong interaction between ferric oxide and $\mathrm{Pt}$, leading to a stabilization of the non-PGM overlayer. It is of interest to note that $\mathrm{Pt} @ \mathrm{Fe}_{2} \mathrm{O}_{3}$ nanoparticles are well known in the field of materials science, with potential applications in magnetic storage, catalysis and biological labelling. ${ }^{56-59}$ These novel structural insights into the nature of $\mathrm{Pt}$ in $\mathrm{Pt}_{1.0} \mathrm{Fe}_{1.0} \mathrm{~d}$ and $\mathrm{Pt}_{2.0} \mathrm{Fe}_{1.0} \mathrm{~d}$ also raise new questions on the true reason for 
the observed durability of these hybrid catalysts in PEMFC. Do Pt@ $\mathrm{Fe}_{2} \mathrm{O}_{3}$ nanoparticles act as scavengers for peroxide or reactive oxygen species, protecting the $\mathrm{FeN}_{\mathrm{x}}$ active sites from deactivation or degradation? Or do they have intrinsic ORR activity that is comparable to that of $\mathrm{FeN}_{\mathrm{x}}$ active sites, leading to apparent similar ORR activities for $\mathrm{Fe}_{1.0} \mathrm{~d}, \mathrm{H}_{2}-\mathrm{Fe}_{1.0} \mathrm{~d}, \mathrm{Pt}_{1.0} \mathrm{Fe}_{1.0} \mathrm{~d}$ and $\mathrm{Pt}_{2.0} \mathrm{Fe}_{1.0} \mathrm{~d}$ ? To disentangle these different possibilities, we performed studies on model flat surfaces of $\mathrm{Fe}_{2} \mathrm{O}_{3}$ layers of controlled thickness grown on $\operatorname{Pt}(111)$.

$\mathrm{Fe}_{2} \mathrm{O}_{3} / \mathrm{Pt}(111)$ model surfaces were prepared according to a modified version of the procedure described by Freund's group. ${ }^{48,60}$ Briefly, iron atoms were evaporated at constant rate on the clean $\operatorname{Pt}(111)$ surface in an atmosphere of $2 \cdot 10^{-5}$ mbar $\mathrm{O}_{2}$ at $800 \mathrm{~K}$. To improve the crystalline order and guarantee complete oxidation, a post annealing at $1050 \mathrm{~K}$ in $4 \cdot 10^{-3}$ mbar $\mathrm{O}_{2}$ for 45 minutes was necessary. The atomic structure and chemical composition of the resulting $\mathrm{Fe}_{2} \mathrm{O}_{3}$ ultrathin films were investigated by low energy electron diffraction (LEED) and X-ray photoemission spectroscopy (XPS). Figure S4 reports the LEED patterns of the clean $\mathrm{Pt}(111)$ substrate and of $\mathrm{Fe}_{2} \mathrm{O}_{3} / \mathrm{Pt}(111)$ ultrathin film with an average thickness of $3.2 \mathrm{~nm}$, as determined by angle-resolved(AR)-XPS measurements. The diffraction pattern corresponds to a $\alpha-\mathrm{Fe}_{2} \mathrm{O}_{3}(0001)-(1 \times 1)$ surface with a hexagonal unit cell with a lattice constant of 5.0 $\AA$ that is rotated by $30^{\circ}$ with respect to the unit cell of the $\operatorname{Pt}(111)$ surface. ${ }^{47}$ 

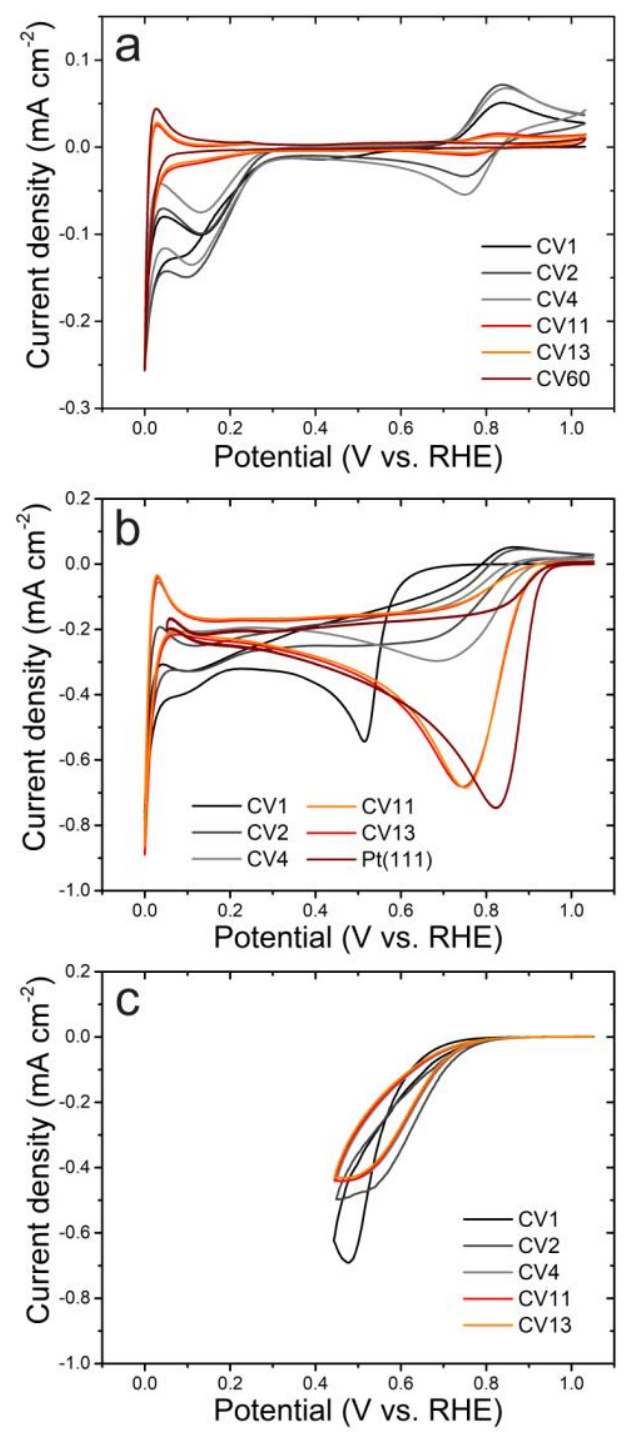

Figure 3. Cyclic voltammograms of the 3.2- $\mathrm{Fe}_{2} \mathrm{O}_{3} / \mathrm{Pt}(111)$ film in (a) Ar-saturated and (b-c) $\mathrm{O}_{2-}$ saturated $0.1 \mathrm{M} \mathrm{HClO}_{4}$ solution at a scan rate of $20 \mathrm{mV} \cdot \mathrm{s}^{-1}$ between (a-b) 1.05 and $0.0 \mathrm{~V} v s$. RHE and (c) 1.05 and $0.45 \mathrm{~V}$ vs. RHE.

The stoichiometry of the $\mathrm{Fe}_{2} \mathrm{O}_{3}$ ultrathin film is confirmed by the $\mathrm{Fe}_{2 \mathrm{p}}$ core-level XPS data reported in Figure S5a. A clear satellite is observed at a binding energy of $719.3 \mathrm{eV}$, which is associated with $\mathrm{Fe}^{3+}$ species $^{61}$. Moreover, the $\mathrm{O}_{1 \mathrm{~s}}$ photoemission line (Figure S5b) exhibits only one component at $529.5 \mathrm{eV}$, indicating a pure hematite phase ${ }^{61}$. Lastly, the $\mathrm{Fe} / \mathrm{O}$ atomic ratio determined by XPS was $2 / 3$, as expected for pure $\mathrm{Fe}_{2} \mathrm{O}_{3}$. To confirm the full coverage of the $\operatorname{Pt}(111)$ surface by the iron oxide layer, the $\mathrm{C}_{1 \mathrm{~s}}$ energy region was checked after dosing hundreds of Langmuir of $\mathrm{CO}$ at room temperature. The lack of any $\mathrm{C}_{1 \mathrm{~s}}$ signal confirmed the absence of adsorbed $\mathrm{CO}$, implying the absence of surface-exposed $\mathrm{Pt}$ 
sites. By adopting the same synthesis protocol, but reducing the amount of the evaporated Fe, it was possible to grow $\mathrm{Fe}_{2} \mathrm{O}_{3}$ with thickness of $1.0,1.6 \mathrm{~nm}$ and $6.4 \mathrm{~nm}$, with analogous structural and morphological properties. This gives us therefore four model surfaces with thickness of 1.0, 1.6, 3.2 and $6.4 \mathrm{~nm}$ of $\mathrm{Fe}_{2} \mathrm{O}_{3}$ on $\mathrm{Pt}(111)$, labelled as $\mathrm{x}-\mathrm{Fe}_{2} \mathrm{O}_{3} / \mathrm{Pt}(111)$ where $\mathrm{x}$ is the thickness in nm. For the thinnest film of $1 \mathrm{~nm}$, we verified again with XPS of $\mathrm{C}_{1 \mathrm{~s}}$, after dosing hundreds of Langmuir of $\mathrm{CO}$ at room temperature, that no $\mathrm{CO}$ adsorbed on the $1.0-\mathrm{Fe}_{2} \mathrm{O}_{3} / \mathrm{Pt}(111)$ film, verifying the absence of surfaceexposed Pt (Figure S6).

The electrochemical stability of the $3.2-\mathrm{Fe}_{2} \mathrm{O}_{3} / \mathrm{Pt}(111)$ film was evaluated ex situ by cyclic voltammetry $(\mathrm{CV})$ in Ar- or $\mathrm{O}_{2}$-saturated $0.1 \mathrm{M} \mathrm{HClO}_{4}$ solution using a standard three-electrode cell. Figure 3a shows the CVs measured in Ar-saturated electrolyte between $1.05 \mathrm{~V}$ and $0.0 \mathrm{~V}$ vs. RHE. The negativeand positive-going scans of the second $\mathrm{CV}(\mathrm{CV} 2)$ show two redox peaks at $0.75 \mathrm{~V}$ and $0.83 \mathrm{~V} v$. RHE, respectively. Those peaks are absent from the $\mathrm{CV}$ of the clean $\mathrm{Pt}(111)$ surface (not shown) and can therefore be associated with the $\mathrm{Fe}^{3+} / \mathrm{Fe}^{2+}$ redox couple. Their intensity is decreasing with the number of cycles (CV4 to CV60), suggesting the progressive dissolution of the $\alpha-\mathrm{Fe}_{2} \mathrm{O}_{3}$ film. This interpretation is supported by XPS measurements showing a constant decrease of the ratio $\mathrm{Fe}_{2 \mathrm{p}} / \mathrm{Pt}_{4 \mathrm{f}}$ from the photoemission peaks (not shown). Interestingly, the redox couple is not observed when the 3.2$\mathrm{Fe}_{2} \mathrm{O}_{3} / \mathrm{Pt}(111)$ surface is cycled between 0.55 and $1.05 \mathrm{~V}$ vs. RHE (see Figure S7). The appearance of the redox couple centered at $0.79 \mathrm{~V} v s$. RHE seems therefore conditioned by the previous occurrence of the reduction event related with the reduction peak observed at $c a .0 .12 \mathrm{~V} v s$. RHE in the negative-going scans (CV1-4 in Figure 3a). This is especially obvious for CV1, where no reduction peak is observed at $0.75 \mathrm{~V}$ vs. RHE in the first negative-going scan while the oxidation peak at $0.83 \mathrm{~V}$ is clearly visible in the subsequent positive-going scan. This might imply that the $\mathrm{Fe}^{3+} / \mathrm{Fe}^{2+}$ redox couple is not intrinsic to $\alpha-\mathrm{Fe}_{2} \mathrm{O}_{3}$ phase itself, but stems from a reduced Fe oxide top-surface layer formed on the surface of $\alpha$ $\mathrm{Fe}_{2} \mathrm{O}_{3}$ while the potential applied is in the range of 0.12-0.0 V vs. RHE. 
A very similar behavior is observed when the acid medium is saturated with oxygen. When scanning the potential in the window $1.05-0.0 \mathrm{~V} v s$. RHE (Figure 3b), the iron oxide layer is progressively dissolved as deduced from the shift of the onset potential of the ORR toward more positive values, characteristic for a bare $\mathrm{Pt}(111)$ surface. Analogous conclusion of identical dissolution behavior in Arand $\mathrm{O}_{2}$-saturated acid electrolytes can also be deduced from the analysis of the $\mathrm{Fe}_{3 \mathrm{p}} / \mathrm{Pt}_{4 \mathrm{f}}$ photoemission signal, which eventually strongly decreases after several cycles in the $0.0-1.05 \mathrm{~V}$ potential window, regardless of the Ar- or $\mathrm{O}_{2}$-saturation (Figure S8a).

In order to avoid dissolution of $\mathrm{Fe}_{2} \mathrm{O}_{3}$ in the subsequent experiments, the lower-limit potential during the scans was set to $0.45 \mathrm{~V}$ vs. RHE, well above the onset of the reduction peak of the $\mathrm{Fe}_{2} \mathrm{O}_{3}$ film located at $c a 0.3 \mathrm{~V}$ vs. RHE. The CVs were recorded until a stable response was observed, then the sample was analyzed by XPS to determine possible chemical transformations as well as to measure the Fe-oxide film thickness. No chemical changes were induced in those cycling conditions (13 cycles between 1.05 and $0.45 \mathrm{~V}$ vs. RHE in $\mathrm{O}_{2}$-saturated $0.1 \mathrm{M} \mathrm{HClO}_{4}$, Figure $\mathbf{S 8 b}$, curve 4) and the thickness of the iron oxide film after the cycling was estimated to be $92 \pm 4 \%$ of the initial value. These results indicate that the Pt substrate stabilizes the $\alpha-\mathrm{Fe}_{2} \mathrm{O}_{3}$ thin film in acidic medium in the potential region $0.45-1.05 \mathrm{~V} v s$. RHE.
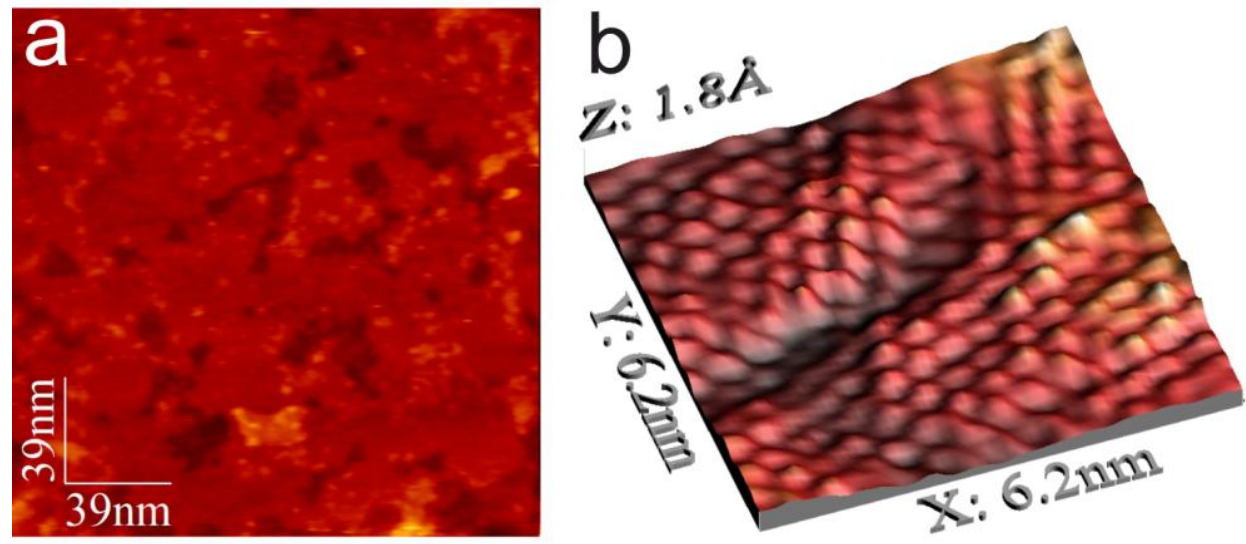
Figure 4. Low- (a) and high-resolution EC-STM images (b) of 1.6- $\mathrm{Fe}_{2} \mathrm{O}_{3} / \mathrm{Pt}(111)$ in Ar-saturated $0.1 \mathrm{M}$ $\mathrm{HClO}_{4}$ solution at $1.05 \mathrm{~V}$ vs. RHE. Tunneling parameters: $\mathrm{U}_{\mathrm{b}}=-900 \mathrm{mV}, \mathrm{I}_{\mathrm{t}}=4.8 \mathrm{nA}(\mathrm{a})$ and $\mathrm{U}_{\mathrm{b}}=-697$ $\mathrm{mV}, \mathrm{I}_{\mathrm{t}}=4.8 \mathrm{nA}(\mathrm{b})$.

In order to get an insight at the atomic level into the morphology and stability of the $\mathrm{Fe}_{2} \mathrm{O}_{3} / \mathrm{Pt}(111)$ system, the film with a nominal thickness of $1.6 \mathrm{~nm}$ was investigated by in situ electrochemical scanning tunneling microscopy (EC-STM). This technique directly demonstrates the stability of the $\mathrm{Fe}_{2} \mathrm{O}_{3} / \mathrm{Pt}(111)$ system even at the atomic level. Figure 4 shows low- and high-resolution STM images acquired in Ar-saturated $0.1 \mathrm{M} \mathrm{HClO}_{4}$ solution at $1.05 \mathrm{~V}$ vs. RHE. The $\mathrm{Fe}_{2} \mathrm{O}_{3}$ layer fully covers the $\operatorname{Pt}(111)$ surface, forming flat terraces characterized by an average surface roughness $\left(\mathrm{R}_{\mathrm{a}}\right)$ and root mean square (RMS) roughness (see supporting information for details) for of $\sim 0.9$ and $\sim 1.3 \AA$, respectively, where a primitive hexagonal unit cell, with the lattice parameter of $\sim 5 \AA$ can be clearly identified (Figure 4b).

Figure S9 reports a series of potentiodynamic EC-STM images starting from $1.05 \mathrm{~V}$ down to $0.45 \mathrm{~V} v s$. RHE. The red arrow on all panels indicates the same position on the surface. The electrode potential was scanned in the cathodic direction without observing any significant change on the surface (Figure S9b-c). Then, the potential was scanned back up to $1.05 \mathrm{~V}$ vs. RHE (Figure S9d-f). No changes in the morphology were observed in this potential window (0.45-1.05 V vs. RHE). Moreover, no differences were observed after $24 \mathrm{~h}$ in $0.1 \mathrm{M} \mathrm{HClO}_{4}$ at $0.6 \mathrm{~V} v s$. RHE and 100 cycles between $1.05 \mathrm{~V}$ and $0.45 \mathrm{~V}$ vs. RHE (Figure S10a) which is confirmed by the $\mathrm{R}_{\mathrm{a}}$ and RMS roughness analysis (Table S2). No Pt features were observed also in the $\mathrm{CV}$ in the region of 0.45 to $1.05 \mathrm{~V}$ vs. RHE, after the same protocol (Figure S10b), indicating that no Pt surface was exposed even after potential hold and potential cycling in this potential range. Overall, the experimental data suggest that in the potential window $0.45-1.05 \mathrm{~V}$ $v s$. RHE, the ultrathin hematite film is highly stable in acid conditions. The origin of this high stability is not clear yet, and several phenomena could be involved. Recent DFT calculations ascribed the increased 
stability in alkaline conditions of $\mathrm{NiO}_{\mathrm{x}}$ ultrathin films on $\mathrm{Pt}(111)$ surface with respect to the bulk counterpart to the strong adhesion energy with the underlying metal ${ }^{62}$. From calculated Pourbaix diagrams, a monolayer of $\mathrm{NiOOH}$ on $\mathrm{Pt}(111)$ was predicted to be stable down to a potential of $c a 0.65$ V vs. RHE while the bulk NiOOH phase was unstable already below $1.4 \mathrm{~V}$ vs. RHE. ${ }^{62}$ Similar strong stabilization was also calculated for $\mathrm{Mn}$ - and Co-oxy(hydroxides) on $\mathrm{Pt}(111)$ vs. the bulk oxy(hydroxides). ${ }^{62}$ The magnitude of stabilization predicted for these metal-oxy(hydroxides) films on $\mathrm{Pt}(111)$ are compatible with the stability down to $0.45 \mathrm{~V}$ vs. RHE for $\mathrm{Fe}_{2} \mathrm{O}_{3}$ thin film on $\mathrm{Pt}(111)$ observed in this work. In addition, the peculiar electronic properties of ultrathin films and changes in the electronic structure at the interface between $\mathrm{Fe}_{2} \mathrm{O}_{3}$ and $\mathrm{Pt}(111)$ can play a role. In particular, the $\mathrm{Pt}$ $5 \mathrm{~d}$ band strongly hybridizes with Fe $3 \mathrm{~d}$ and $\mathrm{O} 2 \mathrm{p}$ states at the interface and even in the inner layers ${ }^{63,64}$, which can influence the stability of the films. 

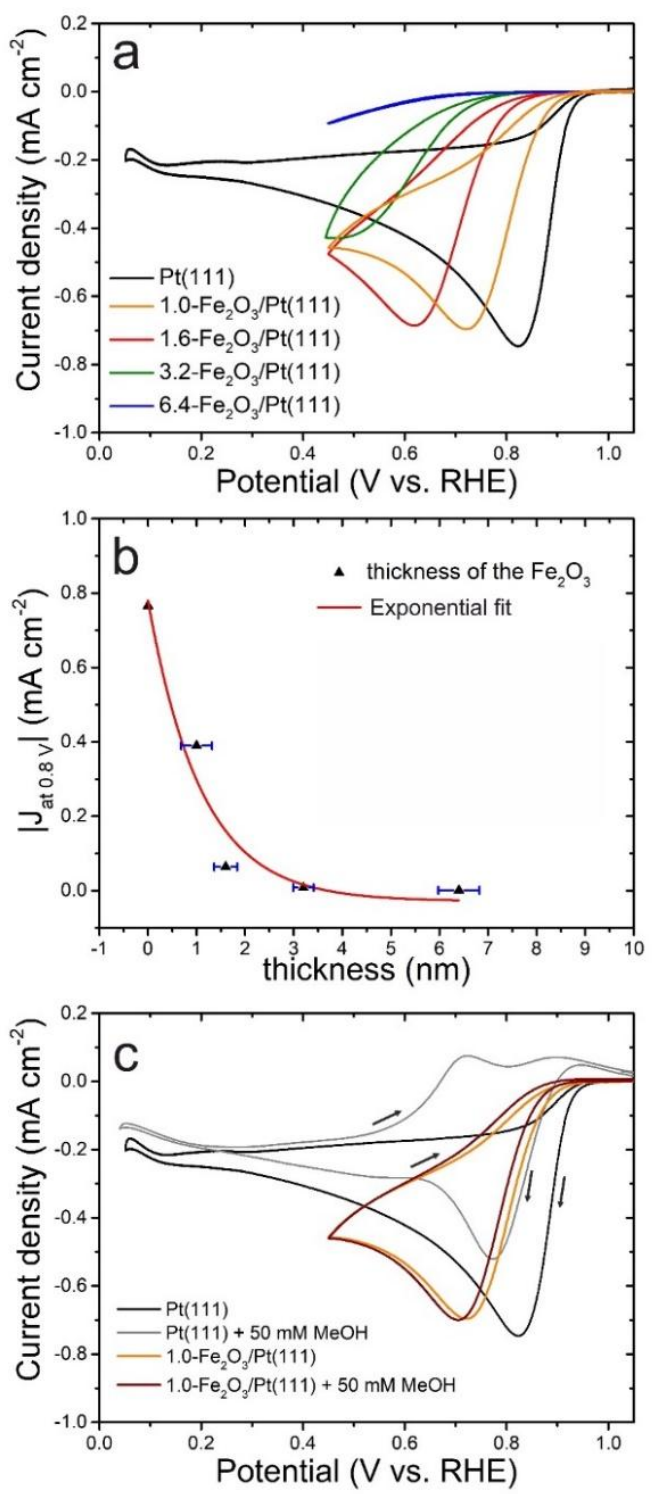

Figure 5. a) Comparison of CVs for the different thickness of $\mathrm{Fe}_{2} \mathrm{O}_{3} / \mathrm{Pt}(111)$ in $\mathrm{O}_{2}$-saturated $0.1 \mathrm{M}$ $\mathrm{HClO}_{4}$ electrolyte; b) Absolute value of ORR current density at $0.8 \mathrm{~V}$ vs. RHE measured with $\mathrm{CV}_{\text {in }} \mathrm{O}_{2-}$ saturated $0.1 \mathrm{M} \mathrm{HClO}_{4}$ as a function of the thickness of the $\mathrm{Fe}_{2} \mathrm{O}_{3}$ thin-film layer on $\mathrm{Pt}(111)$. The red curve shows the fitting of the experimental data with an exponentially decreasing law (see Table S4); c) Effect of addition of $50 \mathrm{mM}$ methanol to the CVs of $1.0-\mathrm{Fe}_{2} \mathrm{O}_{3} / \mathrm{Pt}(111)$ and $\mathrm{Pt}(111)$ in $\mathrm{O}_{2}$-saturated 0.1 $\mathrm{M} \mathrm{HClO}_{4}$ solution. The scan rate was $20 \mathrm{mV} \mathrm{s}^{-1}$ for all measurements.

Let us know examine the ORR activity of the different $\mathrm{Fe}_{2} \mathrm{O}_{3} / \mathrm{Pt}(111)$ films. When examining the 3.2$\mathrm{Fe}_{2} \mathrm{O}_{3} / \mathrm{Pt}(111)$ film that has been discussed hitherto, we find a poor ORR activity in comparison to the 
clean $\operatorname{Pt}(111)$ surface, with $\mathrm{ca} 300 \mathrm{mV}$ negative shift (compare the green and black curves in Figure 5a). On the other hand, the STEM analysis of the core $@$ shell particles in $\mathrm{Pt}_{2.0} \mathrm{Fe}_{1.0} \mathrm{~d}$ revealed a thickness of the $\mathrm{Fe}_{2} \mathrm{O}_{3}$ shell below $1.5 \mathrm{~nm}$. Therefore, the effect of the iron oxide film thickness on the ORR activity was further investigated on the 1.0-, 1.6- and 6.4- $\mathrm{Fe}_{2} \mathrm{O}_{3} / \mathrm{Pt}(111)$ films. As observed in Figure 5a, there is an inverse correlation between ORR activity and the $\mathrm{Fe}_{2} \mathrm{O}_{3}$ film thickness for the $\mathrm{Fe}_{2} \mathrm{O}_{3} / \mathrm{Pt}(111)$ ultrathin films. At the lowest thickness $(1.0 \mathrm{~nm})$, the kinetically controlled region of the polarisation curve of $1.0-\mathrm{Fe}_{2} \mathrm{O}_{3} / \mathrm{Pt}(111)$ is $c a$ only $80 \mathrm{mV}$ negative compared to that of clean $\mathrm{Pt}(111)$. In terms of ORR activity at $0.9 \mathrm{~V} v s$. RHE, the 1.6 and $1.0 \mathrm{~nm}$ Fe-oxide layers on $\mathrm{Pt}(111)$ reach $c a 1 / 70^{\text {th }}$ and $1 / 8^{\text {th }}$ the ORR activity of $\operatorname{Pt}(111)$, respectively. This is because although the metal surface is fully covered by $\alpha-\mathrm{Fe}_{2} \mathrm{O}_{3}$, even for the $1.0 \mathrm{~nm}$ thick film, the electrons from the Pt metallic substrate can tunnel through the oxide layer and catalyze the oxygen reduction on the electrode surface ${ }^{65-67}$. As the oxide thickness increases, tunneling is progressively suppressed and the top surface then shows catalytic properties similar to the bulk phase of the overlayer, with little to no ORR activity expected for bulk $\mathrm{Fe}_{2} \mathrm{O}_{3}$ in acidic medium. Figure $\mathbf{5 b}$ and $\mathbf{S 1 1}$ better show the correlation between $\mathrm{Fe}_{2} \mathrm{O}_{3}$ layer thickness and ORR activity at 0.8 and $0.9 \mathrm{~V} v s$. RHE, respectively. The lower potential of $0.8 \mathrm{~V}$ allows a more accurate reading of $\mathrm{ORR}$ activity for thick $\mathrm{Fe}_{2} \mathrm{O}_{3}$ overlayer, while $0.9 \mathrm{~V}$ is more convenient to compare to the ORR activity measured for a bare $\mathrm{Pt}(111)$ surface. In both cases, the experimental data of ORR activity vs. $\mathrm{Fe}_{2} \mathrm{O}_{3}$ thickness could be fitted with an exponentially-decaying law, supporting the electron tunneling hypothesis.

These results suggest that the observed ORR activity in the $\mathrm{Pt} / \mathrm{FeNC}$ powder catalysts may arise in part from Pt@ $\mathrm{FeO}_{\mathrm{x}}$ nanostructures and not only from $\mathrm{FeN}_{\mathrm{x}}$ centers. To estimate the activity that may be expected from $\mathrm{Pt} @ \mathrm{Fe}_{2} \mathrm{O}_{3}$ nanostructures in the $\mathrm{Pt}_{2.0} \mathrm{Fe}_{1.0} \mathrm{~d}$ powder $\left(\mathrm{J}_{\mathrm{Fe} 2 \mathrm{O} 3}\right)$, one needs to estimate the surface specific activity of $\mathrm{Fe}_{2} \mathrm{O}_{3}\left(\mathrm{i}_{\mathrm{s}}\right)$ and the surface area of $\mathrm{Fe}_{2} \mathrm{O}_{3}$ in the $\mathrm{Pt} / \mathrm{FeNC}$ layer per geometric area of glassy carbon (S). The value of $i_{S}$ may be estimated from the Faradaic current density observed at $0.8 \mathrm{~V}$ vs. RHE in Figure 5a, red curve $\left(0.065 \mathrm{~mA} \cdot \mathrm{cm}^{-2}\right)$, corresponding to the $1.6 \mathrm{~nm}$ thick film. The latter is close to the Fe-oxide thicknesses observed in $\mathrm{Pt}_{2.0} \mathrm{Fe}_{1.0} \mathrm{~d}$. Then, the surface area of $\mathrm{Fe}_{2} \mathrm{O}_{3}$ in the 
RDE active layer can be estimated assuming that the Pt cores have a single diameter, $r$ (assumed between 2.5 and $4.0 \mathrm{~nm}$ ), and the Fe-oxide shells have a fixed thickness of $1.6 \mathrm{~nm}$ (see supporting text). The calculations lead to S-values between $\mathrm{ca} 11$ and $24 \mathrm{~cm}^{2} \mathrm{Fe}_{2} \mathrm{O}_{3}$ per $\mathrm{cm}^{2}$ geometric area for $\mathrm{r}=4$ and $2.5 \mathrm{~nm}$, respectively. The former radius seems to better represent $\mathrm{Pt}_{2.0} \mathrm{Fe}_{1.0}$ d, leading to $\mathrm{ca} 0.6 \mathrm{wt} \% \mathrm{Fe}$ being present as $\mathrm{Fe}_{2} \mathrm{O}_{3}$ ( ca $20 \%$ relative to all $\mathrm{Fe}$ ), in line with the ${ }^{57} \mathrm{Fe}$ Mössbauer spectroscopy analysis (Table S1, 16\% Fe as Fe-oxide). The Pt core radius of $4 \mathrm{~nm}$ is also in line with the most frequent particle size of ca $8 \mathrm{~nm}$ reported by us previously for these Pt/FeNC materials (Figure 2 of Ref. ${ }^{46}$ ). The expected contribution to the ORR activity at $0.8 \mathrm{~V} v s$. RHE is then $0.71 \mathrm{~mA} \cdot \mathrm{cm}^{-2}$ (Table S3). This is significantly lower than the total ORR activity of $\mathrm{Pt}_{2.0} \mathrm{Fe}_{1.0} \mathrm{~d}$ in $0.1 \mathrm{M} \mathrm{HClO}_{4}$ at $0.8 \mathrm{~V}$ vs. RHE ( $c$ a $6.8 \mathrm{~mA} \mathrm{~cm}^{-2}$, Figure $6 \mathrm{a}$ in Ref. ${ }^{46}$ ), and seems to support the stabilisation of $\mathrm{FeN}_{\mathrm{x}}$ ORR active sites by less ORR-active $\mathrm{Pt} @ \mathrm{Fe}_{2} \mathrm{O}_{3}$ particles. The calculation is however highly sensitive to the assumed $\mathrm{i}_{\mathrm{s}}$ value, and the conclusion would be changed assuming the $\mathrm{i}_{\mathrm{s}}$-value measured for $1 \mathrm{~nm} \mathrm{Fe}_{2} \mathrm{O}_{3}$ thickness $\left(0.4 \mathrm{~mA} \cdot \mathrm{cm}^{-2}\right)$. Future work with better-defined materials, in particular with more uniform Pt particle size in such $\mathrm{Pt} / \mathrm{FeNC}$ composites, will thus be necessary to strengthen this conclusion, since the calculations also show that the assumed Pt core radius strongly affects the ORR activity contribution from $\mathrm{Pt} @ \mathrm{Fe}_{2} \mathrm{O}_{3}$ particles for a fixed Pt content of 2 wt $\%$ (Table S3).

Finally, the methanol tolerance of the $1.0-\mathrm{Fe}_{2} \mathrm{O}_{3} / \mathrm{Pt}(111)$ film was investigated using our model systems. CVs were recorded for $\mathrm{Pt}(111)$ and $1.0-\mathrm{Fe}_{2} \mathrm{O}_{3} / \mathrm{Pt}(111)$ in $\mathrm{O}_{2}$-saturated $0.1 \mathrm{M} \mathrm{HClO}_{4}$ electrolyte (Figure 5c) before and after adding the amount of methanol necessary to reach a concentration of $50 \mathrm{mM}$. Due to the absence of convection of the electrolyte and semi-infinite diffusion mechanisms, the negativegoing scans identify best the ORR activity (low methanol concentration at the electrode surface, if the surface is methanol-active) while the subsequent positive-going scans identify best the tolerance to methanol $\left(\mathrm{O}_{2}\right.$ concentration at the electrode surface decreased during the negative going scan via ORR, while the methanol concentration was replenished at low potentials). The positive-going scan of the 1.0$\mathrm{Fe}_{2} \mathrm{O}_{3} / \mathrm{Pt}(111)$ surface in $50 \mathrm{mM}$ methanol in $\mathrm{O}_{2}$-saturated $0.1 \mathrm{M} \mathrm{HClO}_{4}$ shows no features of methanol oxidation indicating complete tolerance to methanol (i.e. no activity for methanol oxidation reaction). 
This is also supported by the nearly superimposed negative-going scans in $\mathrm{O}_{2}$-saturated $0.1 \mathrm{M} \mathrm{HClO}_{4}$, with or without $50 \mathrm{mM}$ methanol (orange and red curves in Figure 5c). Such a result is in line with the lack of methanol oxidation activity seen for $\mathrm{Pt}_{1.0} \mathrm{Fe}{ }_{1.0} \mathrm{~d}$ (Figure 1a). In contrast, the positive-going scan of $\mathrm{Pt}(111)$ in $50 \mathrm{mM}$ methanol in $\mathrm{O}_{2}$-saturated $0.1 \mathrm{M} \mathrm{HClO}_{4}$ shows methanol oxidation onset at $c a 0.5$ $\mathrm{V}$ vs. RHE and the sign of the current density even becomes positive $c a 0.7 \mathrm{~V}$ vs. RHE indicating that the methanol oxidation current is larger than the oxygen reduction current. The methanol activity of $\mathrm{Pt}(111)$ is also seen in the difference between the negative-going scans in $\mathrm{O}_{2}$-saturated $0.1 \mathrm{M} \mathrm{HClO}_{4}$, with or without $50 \mathrm{mM}$ methanol (black and grey curves in Figure 5c). In summary, the 1.0$\mathrm{Fe}_{2} \mathrm{O}_{3} / \mathrm{Pt}(111)$ surface is methanol tolerant, revealing that the $1 \mathrm{~nm}$ thick oxide surface on top pf $\mathrm{Pt}(111)$ imparts methanol tolerance, while reducing the ORR activity relative to a bare $\operatorname{Pt}(111)$ surface. A similar enhancement of the poisoning tolerance imparted by ultrathin films has previously been observed for the $\mathrm{Co}_{3} \mathrm{O}_{4} / \mathrm{CoO} / \mathrm{Pd}(100)$ system for ORR in alkaline conditions ${ }^{65}$.

We note that the overall structural and electrochemical characterization results of the present study bear a strong analogy with a recent report from Gasteiger's group on a powder catalyst consisting of Pt nanoparticles deposited on $\mathrm{TiO}_{\mathrm{x}}$, themselves supported on carbon black and finally subjected to a thermal treatment at $400^{\circ} \mathrm{C}$ in $5 \% \mathrm{H}_{2} / \mathrm{Ar}$ (labelled $\mathrm{Pt} / \mathrm{TiO}_{\mathrm{x}} / \mathrm{C}^{400^{\circ} \mathrm{C}, \mathrm{H} 2}$ in Ref. ${ }^{68}$ ). The ORR activity normalized by the Pt mass was 50 times lower for $\mathrm{Pt} / \mathrm{TiO}_{\mathrm{x}} / \mathrm{C}^{400^{\circ} \mathrm{C}, \mathrm{H} 2}$ compared to a reference $\mathrm{Pt} / \mathrm{C}$ material with same Pt particle size. The authors identified Pt@TiO core-shell particles with HR-TEM for particles of $6 \mathrm{~nm}$ and larger, while the detailed structure of smaller particles could not be accessed due to resolution limits. As is the case here and in our previous report, ${ }^{46}$ no $\mathrm{CO}$ stripping and no $\mathrm{H}_{\text {upd }}$ peaks could be observed with $\mathrm{Pt} / \mathrm{TiO}_{\mathrm{x}} / \mathrm{C}^{400^{\circ} \mathrm{C}, \mathrm{H} 2}$. While the tolerance to methanol was not verified in Ref. ${ }^{68}$, it can be expected that $\mathrm{Pt} @ \mathrm{TiO}_{\mathrm{x}}$ particles would also not oxidize methanol. While the authors reported much lower ORR activity for $\mathrm{Pt} / \mathrm{TiO}_{\mathrm{x}} / \mathrm{C}$ than for $\mathrm{Pt} / \mathrm{C}$, comparable activities were observed for the hydrogen oxidation reaction (HOR) in acidic and alkaline medium. ${ }^{6}$ This behavior is, again, strongly analogous to that of $\mathrm{Pt} @ \mathrm{FeO}_{\mathrm{x}}$ core-shell particles, with high HOR activity in acidic medium (Figure 4 in Ref. ${ }^{69}$, HOR polarisation curves labelled D and E corresponding to the catalysts $\mathrm{Pt}_{1.0} \mathrm{Fe}_{1.0} \mathrm{~d}$ 
and $\mathrm{Pt}_{2.0} \mathrm{Fe}_{1.0} \mathrm{~d}$, respectively). The authors in Ref. ${ }^{68}$ proposed that the strongly suppressed ORR activity but retained HOR activity for their Pt@TiO particles relative to Pt particles may be explained by the fact that only the Pt core is electrochemically active and $\mathrm{O}_{2}\left(\right.$ or $\left.\mathrm{H}_{2}\right)$ must diffuse through the $\mathrm{TiO}_{\mathrm{x}}$ overlayer in order to react. The electrochemical results obtained in the present study on model $\mathrm{Fe}_{2} \mathrm{O}_{3} / \mathrm{Pt}(111)$ surfaces however challenge this hypothesis. First, if the Pt core had not modified the electrochemical properties of the Fe-oxide overlayer, the latter should have dissolved very quickly in acidic medium. Second, if the diffusion rate of $\mathrm{O}_{2}$ and $\mathrm{H}_{2}$ through the Fe-oxide layer controlled the ORR and HOR activity, respectively, the results should have shown linear increase of electrochemical activities with decreasing $\mathrm{FeO}_{\mathrm{x}}$ overlayer thickness. However, the present study reveals an exponential increase of ORR activity with decreasing $\mathrm{FeO}_{\mathrm{x}}$ overlayer thickness. This supports an electron tunneling effect from the Pt core through the Fe-oxide layer, the electron tunneling improving both the stability and electrochemical activity of the top surface Fe-oxide.

More theoretical and experimental work is needed however to better understand the relation between the ORR and/or HOR activity of Pt@MO $\mathrm{MO}_{\mathrm{x}}$ core-shell systems and the thickness of the metal-oxide shell (e.g. Pt@ $\mathrm{FeO}_{\mathrm{x}}$ and $\mathrm{Pt} @ \mathrm{TiO}_{\mathrm{x}}$ core-shell systems) and why the methanol oxidation reaction is suppressed altogether. Last, while the model $\mathrm{Fe}_{2} \mathrm{O}_{3} / \mathrm{Pt}(111)$ surfaces reproduce well the general stability and reactivity trends of $\mathrm{Pt} @ \mathrm{FeO}_{\mathrm{x}}$ core-shell particles in the hybrid $\mathrm{Pt} / \mathrm{FeNC}$ catalysts, a notable difference exists in the lower potential limit for stability. While it is $0.45 \mathrm{~V} v s$. RHE for the model surfaces, it is downshifted to at least $0.05 \mathrm{~V}$ vs. RHE for $\mathrm{Pt} @ \mathrm{FeO}_{\mathrm{x}}$ particles in Pt/FeNC catalysts. The latter is deduced from the break-in procedure used in Ref. ${ }^{46}$ for all RDE measurements, consisting of 20 CVs between 0.05 and $1.1 \mathrm{~V}$ vs. RHE. Since this break-in procedure did not remove the Fe-oxide layer (no $\mathrm{H}_{\text {upd }}$ signal characteristic of surface-exposed Pt was observed after the break-in), it can be concluded that the $\mathrm{FeO}_{\mathrm{x}}$ overlayer in $\mathrm{Pt} / \mathrm{FeNC}$ is stable down to this low potential. This different behaviour between model and real catalysts may be due to the presence of different Pt surfaces than $\operatorname{Pt}(111)$, or to strain effects improving the stability of $\mathrm{FeO}_{\mathrm{x}}$ overlayer in the powder catalysts. Support for a much stronger interaction between $\mathrm{FeO}_{\mathrm{x}}$ overlayer and $\mathrm{Pt}$ edge sites as well as $\mathrm{Pt}(100)$ surface relative to that 
for $\mathrm{Pt}(111)$ was recently reported by Wen et al. ${ }^{70}$ Upon formation of $\mathrm{FeO}_{\mathrm{x}}$ by atomic layer deposition (ALD) on Pt nanoparticles, it was observed that the $\mathrm{CO}$ adsorption signal characteristic for $\mathrm{CO} / \mathrm{Pt}(\mathrm{edge})$ decreased most strongly and followed closely by $\mathrm{CO} / \mathrm{Pt}(110)$, while the signal for $\mathrm{CO} / \mathrm{Pt}(111)$ remained intense even after several ALD cycles. This suggests preferential deposition of $\mathrm{FeO}_{\mathrm{x}}$ on $\mathrm{Pt}$ edge sites and $\mathrm{Pt}(100)$ than on $\mathrm{Pt}(111)$. This in turn suggests stronger interaction between $\mathrm{FeO}_{\mathrm{x}}$ and such $\mathrm{Pt}$ sites compared to $\operatorname{Pt}(111)$. This is in line with the stability observed down to lower potential for the powder $\mathrm{Pt} / \mathrm{FeNC}$ catalyst compared to $\mathrm{Fe}_{2} \mathrm{O}_{3}$ model thin-film on $\mathrm{Pt}(111)$.

\section{CONCLUSIONS}

The electrochemical results on the $\mathrm{Pt} / \mathrm{FeNC}$ powder catalysts with $1-2$ wt $\%$ Pt identify complete tolerance to methanol while catalyzing ORR in acidic medium. DMFC polarisation curves with $\mathrm{Pt} / \mathrm{FeNC}$ cathodes comprising only $40-80 \mu \mathrm{g}_{\mathrm{Pt}} \mathrm{cm}^{-2}$ showed promising power performance compared to state-of-art $\mathrm{Pt} / \mathrm{C}$ cathodes with $2000 \mu \mathrm{g}_{\mathrm{Pt}} \mathrm{cm}^{-2}$, allowing the utilization of high methanol concentration $(5 \mathrm{M})$ at the anode without any drawback. STEM-EDXS characterization of the Pt/FeNC material with 2 wt \% Pt identified the encapsulation of Pt nanoparticles by a thin Fe-oxide shell (on average, $1.3 \mathrm{~nm}$ ), i.e. $\mathrm{Pt} @ \mathrm{FeO}_{\mathrm{x}}$ core-shell structures. ${ }^{57} \mathrm{Fe}$ Mössbauer spectroscopy at low temperature identified the coexistence of $\mathrm{Pt} @ \mathrm{FeO}_{\mathrm{x}}$ particles with $\mathrm{FeN}_{\mathrm{x}}$ sites. In order to understand the ORR activity and stability of $\mathrm{Pt} @ \mathrm{FeO}_{x}$ particles, ultrathin films of $\mathrm{Fe}_{2} \mathrm{O}_{3}$ on $\mathrm{Pt}(111)$ were prepared. It was shown that the Fe-oxide layer is stable in acidic medium in the potential range $0.45-1.05 \mathrm{~V}$ vs. RHE, revealing a stabilization of the Fe-oxide by subsurface $\mathrm{Pt}(111)$. While $\mathrm{Fe}_{2} \mathrm{O}_{3}$ overlayers showed similar stability for different $\mathrm{Fe}_{2} \mathrm{O}_{3}$ thicknesses, the ORR activity increased exponentially with decreasing thickness. For example, the ORR activities at $0.9 \mathrm{~V} v s$. RHE of the 1.6 and $1.0 \mathrm{~nm}$ Fe-oxide layers on $\operatorname{Pt}(111)$ were $c a 1 / 70^{\text {th }}$ and $1 / 8^{\text {th }}$ that of $\mathrm{Pt}(111)$, respectively. Both the stability and ORR activity of $\mathrm{Fe}_{2} \mathrm{O}_{3}$ can be explained by electron-tunneling effect from $\operatorname{Pt}(111)$ through the ultrathin Fe-oxide shell. In addition, it is demonstrated that the deposition of even only $1 \mathrm{~nm} \mathrm{Fe}_{2} \mathrm{O}_{3}$ on $\mathrm{Pt}(111)$ renders the surface fully tolerant to methanol. 
From a practical viewpoint for DMFC or other direct alcohol fuel cells cathodes, the results show that Fe-oxide@Pt core particles are promising as i) methanol-tolerant, ii) stable and ORR-active particles in $\mathrm{Pt} / \mathrm{Fe}-\mathrm{N}-\mathrm{C}$ hybrid catalysts and iii) as particles stabilizing neighboring $\mathrm{FeN}_{\mathrm{x}}$ sites. In addition, Feoxide@Pt particles could be promising HOR catalyst for PEMFC anodes, with improved tolerance to many species known to poison exposed Pt nanoparticles.

\section{ASSOCIATED CONTENT}

Supporting Information. Additional STEM-EDXS characterizations of $\mathrm{Pt}_{2.0} \mathrm{Fe}_{1.0} \mathrm{~d} ;{ }^{57} \mathrm{Fe}$ Mössbauer spectroscopy characterization of $\mathrm{Pt}_{2.0} \mathrm{Fe}_{1.0} \mathrm{~d}$; LEED pattern of 3.2- $\mathrm{Fe}_{2} \mathrm{O}_{3} / \mathrm{Pt}(111)$; $\mathrm{O}_{1 \mathrm{~s}}$ and $\mathrm{Fe}_{2 \mathrm{p}} \mathrm{XPS}$ narrow-scan spectra of $3.2-\mathrm{Fe}_{2} \mathrm{O}_{3} / \mathrm{Pt}(111)$; $\mathrm{CV}$ in Ar-saturated $0.1 \mathrm{M} \mathrm{HClO}{ }_{4}$ of $3.2-\mathrm{Fe}_{2} \mathrm{O}_{3} / \mathrm{Pt}(111)$; $\mathrm{Fe}_{3 \mathrm{p}} / \mathrm{Pt}_{4 \mathrm{f}}$ and $\mathrm{Fe} 2 \mathrm{p}$ XPS spectra before and after applying CVs in different conditions; potentiodynamic EC-STM measurements of $1.6-\mathrm{Fe}_{2} \mathrm{O}_{3} / \mathrm{Pt}(111)$; ORR activity vs. $\mathrm{Fe}_{2} \mathrm{O}_{3}$ thickness. This material is available free of charge via the Internet at http://pubs.acs.org.

\section{AUTHOR INFORMATION}

\section{Corresponding Authors}

*frederic.jaouen@umontpellier.fr, stefano.agnoli@unipd.it.

\section{Author Contributions}

The manuscript was written through contributions of all authors. All authors have given approval to the final version of the manuscript.

\section{Funding Sources}

The research leading to these results has received funding from the Fuel Cells and Hydrogen 2 Joint Undertaking under grant agreement No 779366 (CRESCENDO). This joint undertaking receives 
support from the European Union's Horizon 2020 research and innovation programme, Hydrogen Europe and Hydrogen Europe Research. F.J. also acknowledges financial support from AxLR. T.K., S.A. and G.G. also acknowledge financial support from the Italian MIUR (PRIN 2015: SMARTNESS, 2015K7FZLH; PRIN2017: Multi-e, 20179337R7). G. D. acknowledges the financial support from Slovenian Research Agency (P2-0393).

\section{ABBREVIATIONS}

PEMFC, proton exchange membrane fuel cell; DMFC, direct methanol fuel cell; AEM, anion exchange membrane; ORR, oxygen reduction reaction; PGM, platinum group metal; STEM, scanning transmission electron microscopy; EDXS, energy dispersive x-ray spectroscopy; EC-STM, electrochemical scanning tunneling microscopy; CV, cyclic voltammetry; LEED, low energy electron diffraction; XPS, X-ray photoemission spectroscopy; HAADF, high-angle annular dark-field; RHE, reversible hydrogen electrode; SCE, saturated calomel electrode; BE, binding energy.

\section{REFERENCES}

(1) Katsounaros, I.; Cherevko, S.; Zeradjanin, A. R.; Mayrhofer, K. J. J. Angewandte Chemie International Edition 2014, 53, 102-121.

(2) Shao, M.; Chang, Q.; Dodelet, J.; Chenitz, R. Chemical Reviews 2016, 116, 3594-3657.

(3) Wu, Q.; Liang, J.; Yi, J.; Meng, D.; Shi, P.; Huang, Y.; Cao, R. Dalton Trans. 2019, 48, 72117217.

(4) Liang, Y.; Mclaughlin, D.; Csoklich, C.; Schneider, O.; Bandarenka, A. S. Energy \& Environmental Science 2019, 12, 351-357.

(5) Cheng, F.; Chen, J. Chem. Soc. Rev. 2012, 41, 2172-2192. 
(6) He, Q.; Cairns, E. J. Journal of The Electrochemical Society 2015, 162 (14), F1504-F153922.

(7) Erikson, H.; Sarapuu, A.; Tammeveski, K. ChemElectroChem 2019, 6, 73-86.

(8) Ma, R.; Lin, G.; Zhou, Y.; Liu, Q.; Zhang, T. npj Computational Materials 2019, 5, 1-15.

(9) Wang, Y.; Chen, K. S.; Mishler, J.; Chan, S.; Cordobes, X. Applied Energy 2011, 88 (4), 9811007.

(10) Dekel, D. R. Journal of Power Sources 2018, 375, 158-169.

(11) Firouzjaie, H. A.; Mustain, W. E. ACS Catalysis 2020, 10, 225-234.

(12) Zheng, Y.; Omasta, T. J.; Peng, X.; Wang, L.; Varcoe, J. R.; Pivovar, S.; Mustain, W. E. Energy \& Environmental Science 2019, 12, 2806-2819.

(13) Kamarudin, S. K.; Achmad, F.; Daud, W. R. W. International Journal of Hydrogen Energy 2009, 34 (16), 6902-6916.

(14) Li, X.; Faghri, A. Journal of Power Sources 2013, 226, 223-240.

(15) Falcão, D. S.; Oliveira, V. B.; Rangel, C. M.; Pinto, A. M. F. R. Renewable and Sustainable Energy Reviews 2014, 34, 58-70.

(16) Yuan, W.; Zhou, B.; Deng, J.; Tang, Y.; Zhang, Z.; Li, Z. International Journal of Hydrogen Energy 2014, 39 (12), 6689-6704.

(17) Yoshida, T.; Kojima, K. Electrochem. Soc. Interface 2015, 24, 45-49.

(18) Sui, S.; Wang, X.; Zhou, X.; Su, Y.; Riffat, S.; Liu, C.-J. Journal of Materials Chemistry A 2017, $5(5), 1808-1825$.

(19) Ott, S.; Orfanidi, A.; Schmies, H.; Anke, B.; Nong, H. N.; Hübner, J.; Gernert, U.; Gliech, M.; 
Lerch, M.; Strasser, P. Nature Materials 2020, 19 (January), 77-86.

(20) Chattot, R.; Bacq, O. Le; Beermann, V.; Kühl, S.; Herranz, J.; Henning, S.; Kühn, L.; Asset, T.; Guétaz, L.; Renou, G.; Drnec, J.; Bordet, P.; Pasturel, A.; Eychmüller, A.; Schmidt, T. J.; Strasser, P.; Dubau, L.; Maillard, F. Nature Materials 2018, 17 (September), 827-834.

(21) Li, M.; Zhao, Z.; Cheng, T.; Fortunelli, A.; Chen, C.; Yu, R.; Zhang, Q.; Gu, L.; Merinov, B. V; Lin, Z.; Zhu, E.; Yu, T.; Jia, Q.; Guo, J.; Zhang, L.; Huang, Y.; Duan, X. Science 2016, 354 (6318), 1414-1419.

(22) Dhanushkodi, S. R.; Mahinpey, N.; Srinivasan, A.; Wilson, M. Journal of Environmental Informatics 2008, 11 (1), 36-44.

(23) Evangelisti, S.; Tagliaferri, C.; Brett, D. J. L.; Lettieri, P. Journal of Cleaner Production 2017, $142,4339-4355$.

(24) Notter, D. A.; Kouravelou, K.; Karachalios, T.; Daletou, M. K.; Haberland, N. T. Energy \& Environmental Science 2015, 8, 1969-1985.

(25) Chung, H. T.; Cullen, D. A.; Higgins, D.; Sneed, B. T.; Holby, E. F.; More, K. L.; Zelenay, P. Science 2017, 357 (August), 479-484.

(26) Chen, S.; Zhang, N.; Narvaaez Villarrubia, C. W.; Huang, X.; Xie, L.; Wang, X.; Kong, X.; Xu, H.; Wu, G.; Zeng, J.; Wang, H. Nano Energy 2019, 66, 1-8.

(27) Zhang, H.; Chung, H. T.; Cullen, D. A.; Wagner, S.; Kramm, U. I.; More, K. L.; Wu, G. Energy \& Environmental Science 2019, 12, 2548-2558.

(28) Jiao, L.; Li, J.; Richard, L. L.; Stracensky, T.; Liu, E.; Sun, Q.; Sougrati, M.-T.; Zhao, Z.; Yang, F.; Zhong, S.; Xu, H.; Mukerjee, S.; Huang, Y.; Myers, D. J.; Jaouen, F.; Jia, Q. ChemRxiv 2019, $1-19$. 
(29) Ramaswamy, N.; Tylus, U.; Jia, Q.; Mukerjee, S. Journal of the American Chemical Society 2013, $135,15443-15449$.

(30) Jia, Q.; Ramaswamy, N.; Tylus, U.; Strickland, K.; Li, J.; Serov, A.; Artyushkova, K.; Atanassov, P.; Anibal, J.; Gumeci, C.; Barton, S. C.; Sougrati, M. T.; Jaouen, F.; Halevi, B.; Mukerjee, S. Nano Energy 2016, 29, 65-82.

(31) Mineva, T.; Matanovic, I.; Atanassov, P.; Sougrati, M.-T.; Stievano, L.; Clemancey, M.; Latour, J.; Jaouen, F. ACS Catalysis 2019, 9, 9359-9371.

(32) Wagner, S.; Auerbach, H.; Tait, C. E.; Martinaiou, I.; Kumar, S. C. N.; Kübel, C.; Sergeev, I.; Wille, H.-C.; Behrends, J.; Wolny, J. A.; Schünemann, V.; Kramm, U. I. Angewandte Chemie International Edition 2019, 58, 10486-10492.

(33) Shao, Y.; Dodelet, J.; Wu, G.; Zelenay, P. Advanced Materials 2019, 31, 1-8.

(34) Martinez, U.; Babu, S. K.; Holby, E. F.; Zelenay, P. Current Opinion in Electrochemistry 2018, 9, 224-232.

(35) Piela, B.; Olson, T. S.; Atanassov, P.; Zelenay, P. Electrochimica Acta 2010, 55, 7615-7621.

(36) Sebastián, D.; Baglio, V.; Aricò, A. S.; Serov, A.; Atanassov, P. Applied Catalysis B: Environmental 2016, 182, 297-305.

(37) Martinaiou, I.; Monteverde Videla, A. H. A.; Weidler, N.; Kübler, M.; Wallace, W. D. Z.; Paul, S.; Wagner, S.; Shahraei, A.; Stark, R. W.; Specchia, S.; Kramm, U. I. Applied Catalysis B: Environmental 2020, 262, 1-13.

(38) Lo Vecchio, C.; Serov, A.; Romero, H.; Zulevi, B.; Arico, A. S.; Baglio, V. Journal of Power 2019, 437, 1-7.

(39) Santori, P. G.; Speck, F. D.; Li, J.; Zitolo, A.; Jia, Q.; Mukerjee, S.; Cherevko, S.; Jaouen, F. 
Journal of The Electrochemical Society 2019, 166 (7), F3311-F3320.

(40) Chenitz, R.; Kramm, U. I.; Lefevre, M.; Glibin, V.; Zhang, G.; Sun, S.; Dodelet, J.-P. Energy \& Environmental Science 2018, 11, 365-382.

(41) Kumar, K.; Dubau, L.; Mermoux, M.; Li, J.; Zitolo, A.; Nelayah, J.; Jaouen, F.; Maillard, F. Angewandte Chemie 2020, 132, 2-11.

(42) Choi, C. H.; Baldizzone, C.; Polymeros, G.; Pizzutilo, E.; Kasian, O.; Schuppert, A. K.; Ranjbar Sahraie, N.; Sougrati, M. T.; Mayrhofer, K. J. J.; Jaouen, F. ACS Catalysis 2016, 6 (5), 31363146.

(43) Kumar, K.; Gairola, P.; Lions, M.; Ranjbar-Sahraie, N.; Mermoux, M.; Dubau, L.; Zitolo, A.; Jaouen, F.; Mai. ACS Catalysis 2018, 8, 11264-11276.

(44) Goellner, V.; Armel, V.; Zitolo, A.; Fonda, E.; Jaouen, F. Journal of The Electrochemical Society 2015, 6, H403-H414.

(45) Choi, C. H.; Lim, H.-K.; Chung, M. W.; Chon, G.; Ranjbar-Sahraie, N.; Altin, A.; Sougrati, M.T.; Stievano, L.; Oh, H. S.; Park, E. S.; Luo, F.; Strasser, P.; Drazic, G.; Mayrhofer, K. J. J.; Kim, H.; Jaouen, F. Energy \& Environmental Science 2018, 11, 3176-3182.

(46) Mechler, A. K.; Ranjbar-Sahraie, N.; Armel, V.; Zitolo, A.; Sougrati, M.-T.; Schwammlein, J. N.; Jones, D. J.; Jaouen, F. Journal of The Electrochemical Society 2018, 165 (13), 1084-1091.

(47) Shaikhutdinov, S. K.; Weiss, W. Surface Science Letters 1999, 432, L627-L634.

(48) Genuzio, F.; Sala, A.; Schmidt, T.; Menzel, D.; Freund, H. J. Phys. Chem. C 2014, 118, 29068-29076.

(49) Fadley, C. S. Progress in Surface Science 1984, 16 (3), 275-388. 
(50) Wilms, M.; Kruft, M.; Bermes, G.; Wandelt, K. Review of Scientific Instruments 1999, 70 (9), 3641.

(51) Sebastian, D.; Serov, A.; Artyushkova, K.; Atanassov, P.; Arico, A. S.; Baglio, V. Journal of Power 2016, 319, 235-246.

(52) Liu, S.; Wu, J.; Pan, C.; Hwang, B. Journal of Power Sources 2014, 250, 279-285.

(53) Léger, J. M. Journal of Applied Electrochemistry 2001, 31, 767-771.

(54) Gloaguen, F.; Léger, J. M.; Lamy, C. Journal of Applied Electrochemistry 1997, 27, 1052-1060.

(55) Sougrati, M. T.; Goellner, V.; Schuppert, A. K.; Stievano, L.; Jaouen, F. Catalysis Today 2016, $262,110-120$.

(56) Teng, X.; Black, D.; Watkins, N. J.; Gao, Y.; Yang, H. Nano Letters 2003, 3 (2), 261-264.

(57) Sun, Y.; Qin, Z.; Lewandowski, M.; Carrasco, E.; Sterrer, M.; Shaikhutdinov, S.; Freund, H. Journal of Catalysis 2009, 266 (2), 359-368.

(58) Figuerola, A.; Fiore, A.; Corato, R. Di; Falqui, A.; Giannini, C.; Micotti, E.; Lascialfari, A.; Corti, M.; Cingolani, R.; Pellegrino, T.; Cozzoli, P. D.; Manna, L. Journal of the American Chemical Society 2008, No. 11, 1477-1487.

(59) Hong, H.; Hu, L.; Li, M.; Zheng, J.; Sun, X.; Lu, X.; Cao, X.; Lu, J.; Gu, H. Chemistry - A European Journal 2011, 17, 8726-8730.

(60) Kuhlenbeck, H.; Shaikhutdinov, S.; Freund, H. Chemical Reviews 2013, 113, 3986-4034.

(61) Biesinger, M. C.; Payne, B. P.; Grosvenor, A. P.; Lau, L. W. M.; Gerson, A. R.; Smart, R. S. C. Applied Surface Science 2011, 257 (7), 2717-2730.

(62) Zeng, Z.; Chang, K.; Kubal, J.; Markovic, N. M. Nature Energy 2017, 17070 (May), 1-9. 
(63) Neufeld, O.; Toroker, M. C. 2015, 24129-24137.

(64) Mahmoud, A.; Deleuze, P.-M.; Dupont, C. J. Chem. Phys. 2018, 148, 204701-204709.

(65) Kosmala, T.; Calvillo, L.; Agnoli, S.; Granozzi, G. ACS Catalysis 2018, 8 (3).

(66) Shin, D.; Sinthika, S.; Choi, M.; Thapa, R.; Park, N. ACS Catalysis 2014, 4 (11), 4074-4080.

(67) Pacchioni, G.; Freund, H. Chemical Reviews 2013, 113 (6), 4035-4072.

(68) Stühmeier, B. M.; Selve, S.; Patel, M. U. M.; Geppert, T. N.; Gasteiger, H. A.; El-Sayed, H. A. ACS Appl. Energy Mater. 2019, 2, 5534-5539.

(69) Schuppert, A.; Jaouen, F.; Jones, D. WO/2017/042520. WO/2017/042520, 2020.

(70) Wen, Y.; Cai, J.; Zhang, J.; Yang, J.; Shi, L.; Cao, K.; Chen, R.; Shan, B. Chem. Mater. 2019, 2 (100), 101-111.

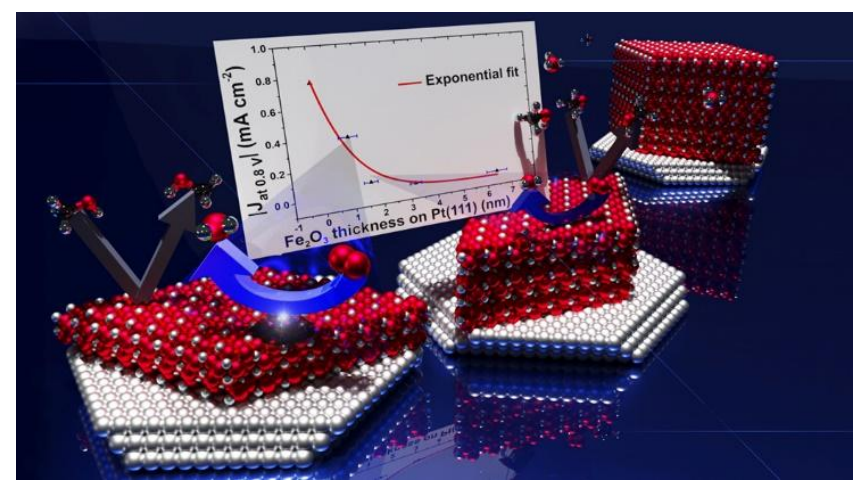


